\title{
السهات القيادية لدى مديري المدارس الثانوية وعلاقتها بتنفيذ القرار في سياسة التعليم
}

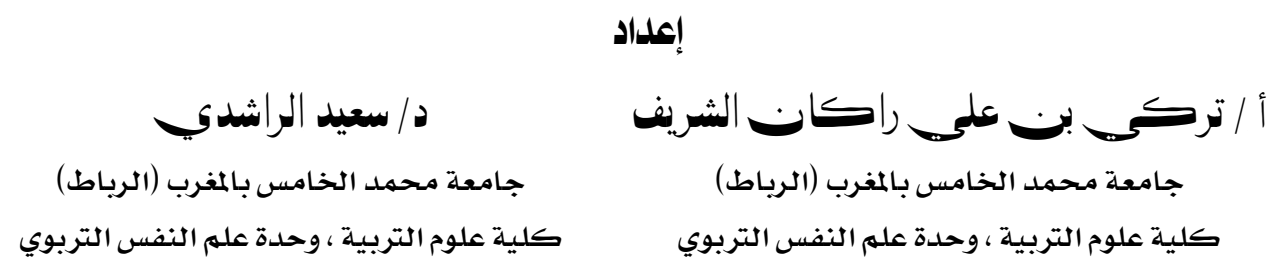

مجلة بحوث التربية النوعية ـ جامعة المنصورة

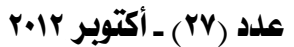




\section{السمات القيادية لدى مدديري المدارس الثانوية}

\section{وعلاقتها بتنفيذ القرار في سياسة التعليم}

إعداد

د/سعيد الراشدي*

* الباحث / تركينعليحاكازالشريف

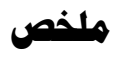

يتكون البحث من مقدمة وثلاثة أبواب وخاتمة :

• البـاب الأول : يتنـاول المرجعيـات النظريـة للبحـث، ويتكون مـن فصلين : يتنـاول الفـصل الأول

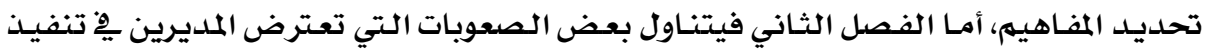

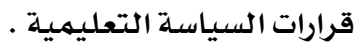

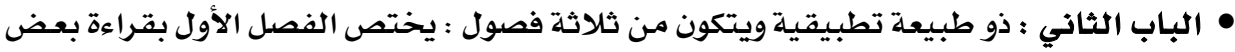

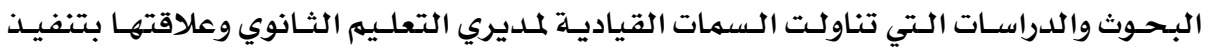

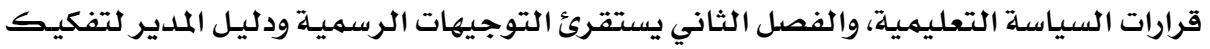

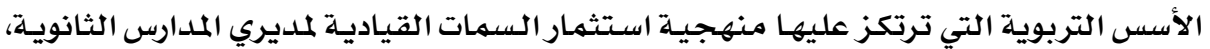

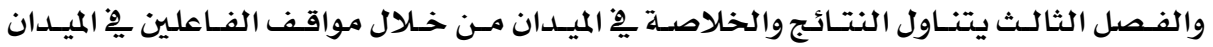

$$
\text { التعليمي. }
$$

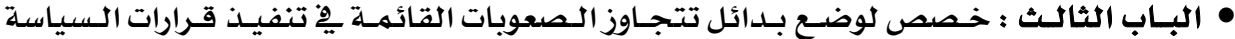

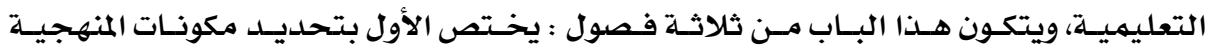

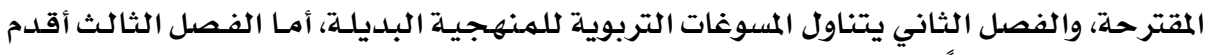

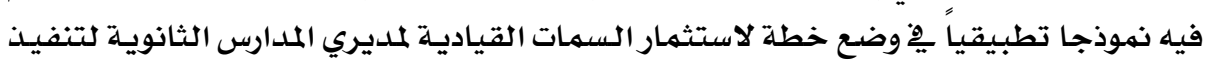
قرارات السياسة التعليمية.

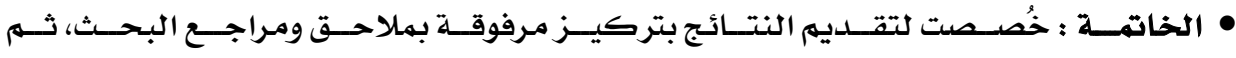
فهرس المحتويات . 


\title{
السمات القيادية للدى هديري المدارس الثانوية \\ وعلاقتها بتنفيذ القرار في سياسة التعليم
}

\author{
إعداد

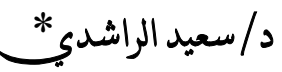 \\ * الباحث/تركينعلمراكانالشريف
}

مقدمهة:

يعالـج هذا البـحث موضوعـاً مـؤرقاً للمسديرين، هو السمات القياديـة لمديري المدارس الثانويـة

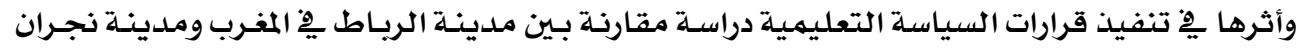

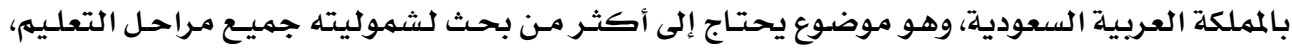

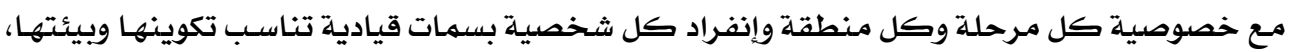

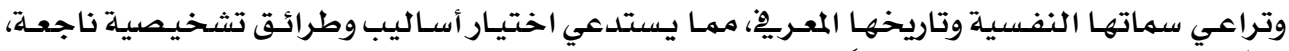

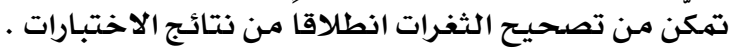

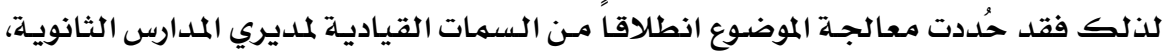

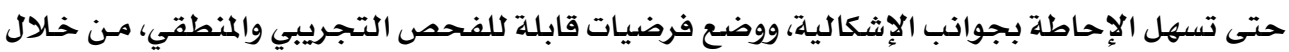

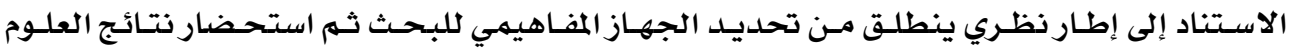

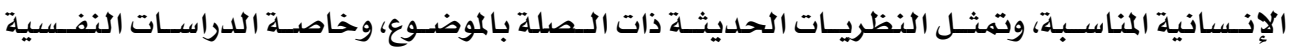

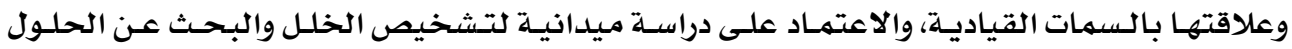

\section{فرضيات البحث:}

\section{• السؤال المركزي:}

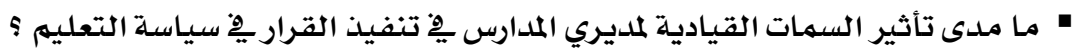

\section{• الأسئلة الفرعية:}

• هل تؤثر السمات القيادية لمديري المدارس الثانوية يِّ تنفيذ القرار فِّ سياسة التعليه ؟

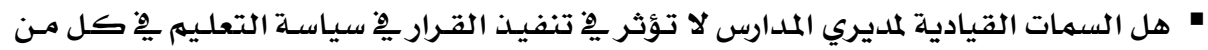

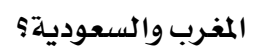

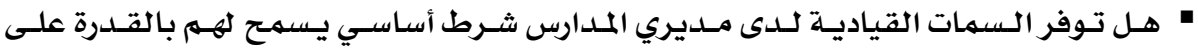

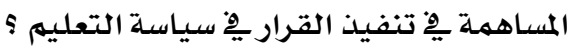

* جامعة محمد الخامس بالمغرب (الرياط) كلية علوم التربية ، وحدة علم النفس التربوي 
• هل هناك علاقة وثيقة بين السمات القيادية لمديري المدارس الثانوية ودورهم مِ عملية تنفيذ

• توضيح المرجعيات النظرية التي سأعتمدها وذلك بتحديد الجهاز المفاهيمي الخاص.

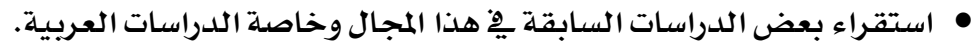

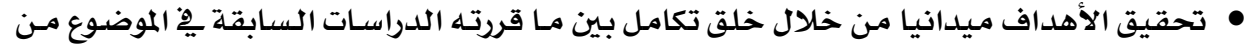

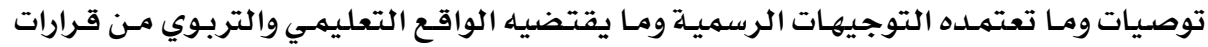

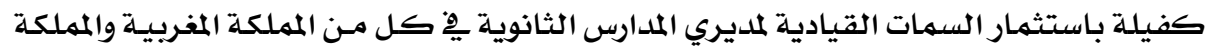

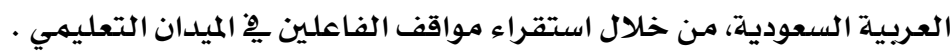

\section{هنهج الدراسة:}

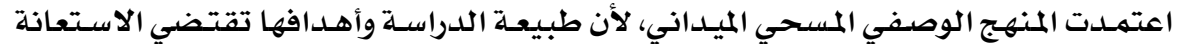

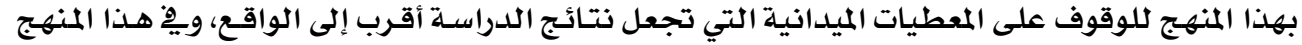

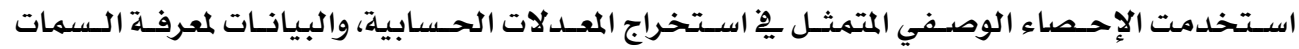

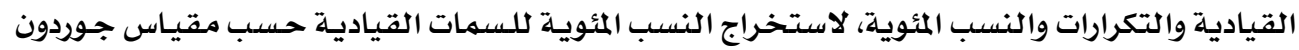
لمديري المدارس الثانويـة وعلاقتها بتنفيذ قرارات السياسة التربوية لاستية.

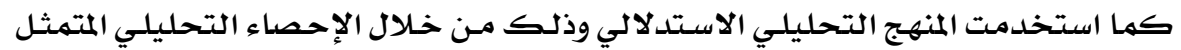

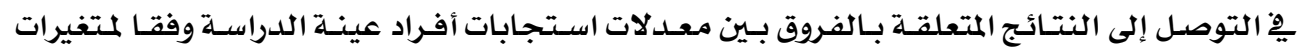

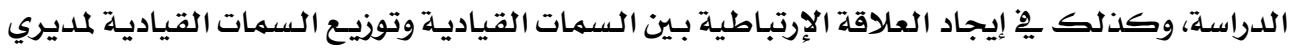
المدارس الثانوية وبين مستوى تنفيذ قرارات السياسة التعليمية.

\section{هتغيزات الدراستة:}

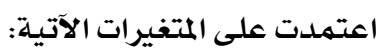

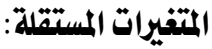

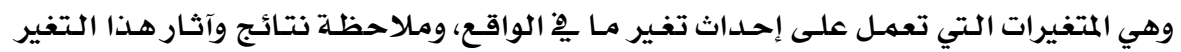

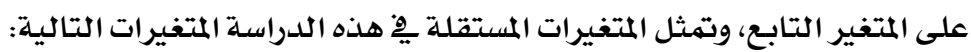

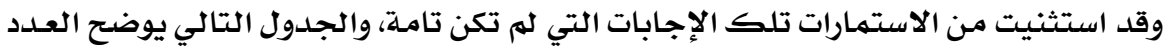

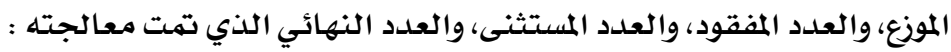

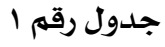

\begin{tabular}{|c|c|c|c|c|}
\hline العلدد المتبقى & العدد المستثنىى & العدد المفقود & العدد الموزع & المتغير \\
\hline r.. & 0. & $1 \ldots$ & \{0. & عينـة الدراسـة \\
\hline
\end{tabular}

والجداول التالية تصف العينة حسب متغيرات الدراسة: 
جدول رقمى

\begin{tabular}{|c|c|c|}
\hline النسبــة & العدد & متغير العمر \\
\hline Ir,OY & r & من ·r إلى ·r \\
\hline $1 \leqslant, 7$ & $\varepsilon \varepsilon$ & مـن · r إلى ·ع \\
\hline 11,77 & 07 & من · ع إلى .0 \\
\hline$r \cdot, 7 T$ & Tr & من · 0 إلى • 7 \\
\hline $01 \ldots$ & r.. & المجموع \\
\hline
\end{tabular}

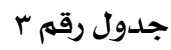

\begin{tabular}{|c|c|c|}
\hline النسبية & العلدد & متغير علدد سنوات الخبرة \\
\hline$r r, r \Lambda$ & VI & من إلى · اسنوات \\
\hline IA,rr & 00 & من II إلى ·rسنـة \\
\hline Y7,77 & $\Lambda$. & من ابrإلى ·r \\
\hline س & $9 \varepsilon$ & من اس فهـا أعلى \\
\hline$\% 1 \ldots$ & $\mu \ldots$ & المجموع \\
\hline
\end{tabular}

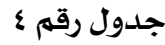

\begin{tabular}{|c|c|c|}
\hline النسبـة & العلدد & متغير الشهادة العلمية أو المهنية \\
\hline$\% 7,77$ & r. & دكتوراه \\
\hline$\%$ \%r,r\& & 1. & ماجستير \\
\hline$\% \wedge$. & $r \varepsilon$. & بكالوريوس \\
\hline$\% 1$. & $r$. & 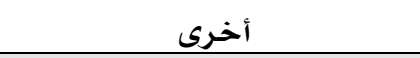 \\
\hline$\% 1 \ldots$ & r.. & المجمبوع \\
\hline
\end{tabular}

جدول رقمه

\begin{tabular}{|c|c|c|}
\hline النسبـة & العددد & متغير الحالة الاجتمهاعيـة \\
\hline \%r,rs & 1. & ذكر أعزب \\
\hline$\% \wedge \Lambda, r \varepsilon$ & r7o & ذ ذكر متزوج \\
\hline$\% 1,77$ & 0 & أنثى عزيـاء \\
\hline \%7,77 & $r$. & أنثى متتزوجـة \\
\hline$\% 1 \ldots$ & $r .$. & المجموع \\
\hline
\end{tabular}




\section{خطوات إجراء الدراسة:}

اتبعت مـجموعة مـن الخطوات للقيام بالدراسـة الميدانية توضسح فيما يلي:

أ. خطوات إعداد أداة الدراسة:

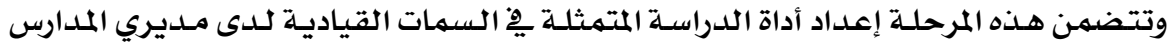

الثانويـة، وتنفيذ السياسـة التعليميـة، وذلك على الشكل التالي :

• التعرف على السهـات القياديـة لـدى مـديري المدارس الثانويـة ِِّ مدينـة نجـران بالمملكـة العربيـة

• التعرف على السعدية . السعات القيادية لدى مديري المدارس الثانويـة يخ مدينـة الرياط .

• التعرف على درجة تنفيذ قرارات السياسـة التعليمية بهـدينة نجران بالمملكة العربية السعودية .

• التعرف على درجة تنفيذ قرارات السياسلة التعليميلة بهـينة الرباط بالمملكة المغربية .

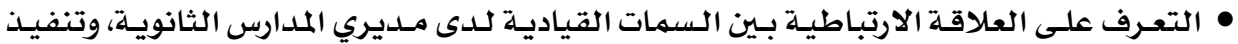

قرارات السياسلة التعليميـة.

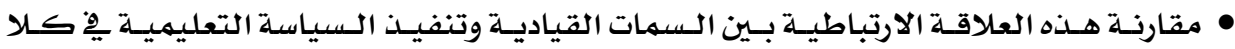

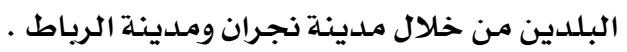

الخطوة الثانية : تحديل مجالات القياس لأداة الدراسة :

تمثلت مجالات القياس لأداة الدراسـة يْ ثلاثة مححاور رئيسـة هي:

ا .المحور الأول :السهـات القيادية التي يمارسها مديري المدارس الثانوية بهمينـة نجران من وجهة

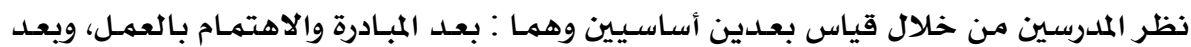

الاهتهمام بالعلاقات الإنسانية.

ץ .المحسور الثاني :السمات الشخهية لمديري المدارس الثانويـة بمدينـة نجـران مـن وجهـة نظر المدرسين من خلال قياس أربعة أبعاد رئيسة للسمات وهي:

( السيطرة، المسئولية، الاتزان الانفعالي، الاجتماعية ).

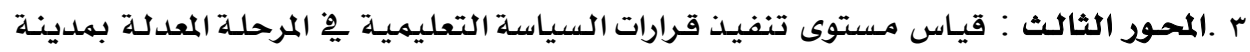

نجران من وجهة نظرهم

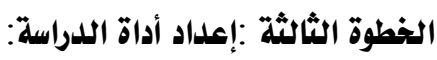

لإععداد فقرات أداة الدراسـة تم عمل الإجراءات التاليـة :

ا. مـراجعـة الأدب النظـري المرتبط بالسهات القياديـة والسمات الشخصية لدى مـديري المدارس

وكذلك المتعلقة بتنفيذ قرارات السياسـة التعليمية يخ مـراحل التعليهم العام.

r. مـراجعـة مقـاييس الدراسـات السـابقة التي استتخدمت للتعـرف على السهمات القياديـة والسسمات

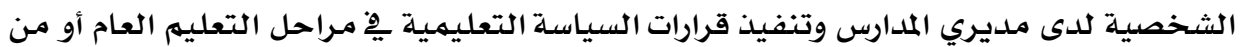

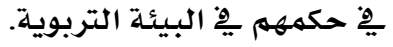


r. مراجعة المصادر السـابقة، والموضوعات المشتملة عليها، من أجل تحديد الأدوات المناسبة لكل محور

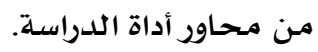

وقد تم إعداد أداة الدراسة حسب ما يلي :

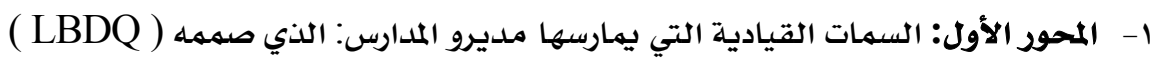

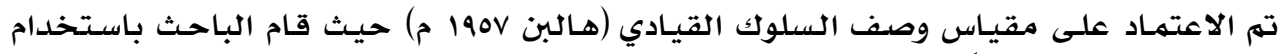

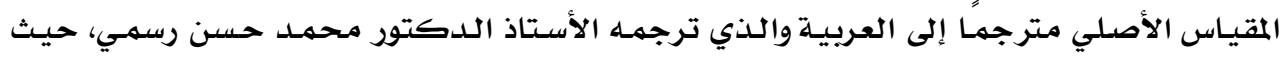

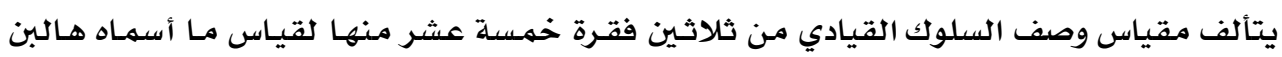

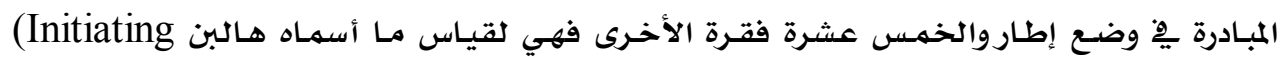

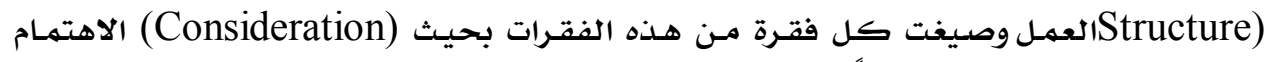

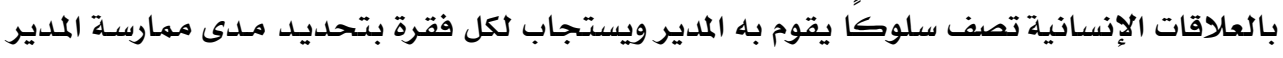
للسلوك الوارد ِِّْ هذه الفقرة حسب المقياس التالي : (دائمًا، غالبًا، أحيانًا، نادرًا، أبدًاً ).

عينة الدراسة:

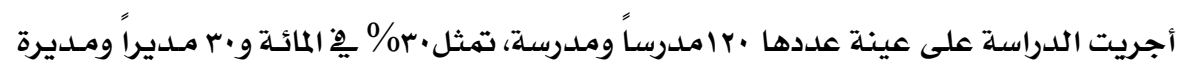

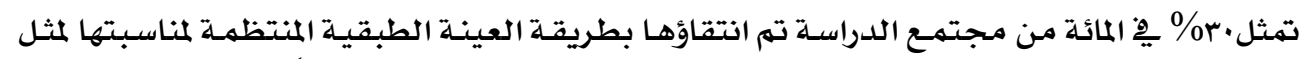

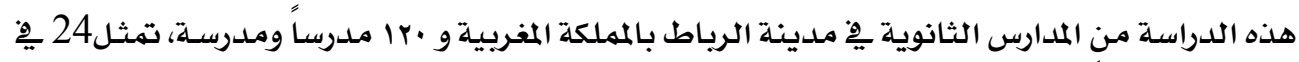

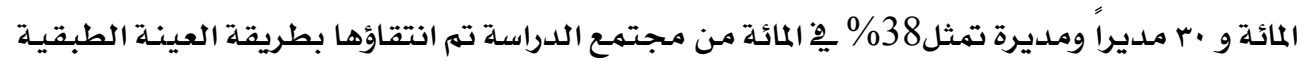

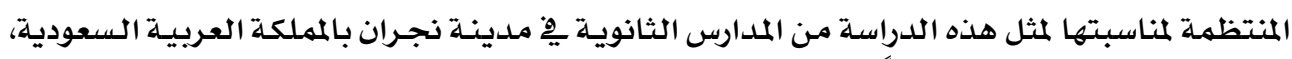

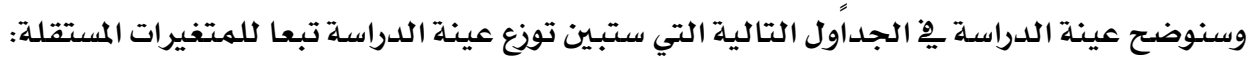

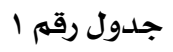

\begin{tabular}{|c|c|c|c|}
\hline نسبتها من المجتمع & النسبة & العدد & المتغير \\
\hline \% & $\% 1 \ldots$ & r... & عينة الدر اسة \\
\hline
\end{tabular}

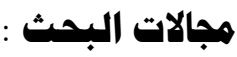

للدراسـة حدود تضمن لها الخصوصية والتركيزوهي على مستويات :

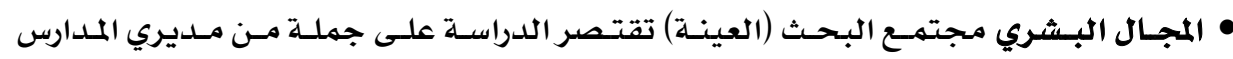

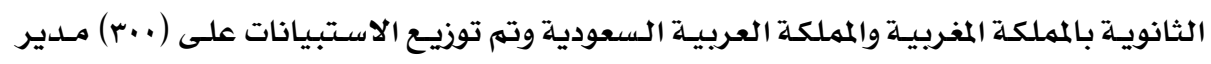

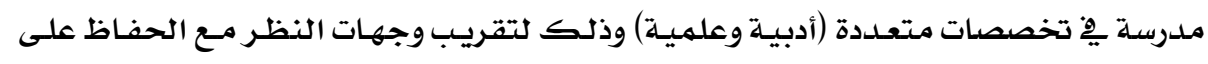

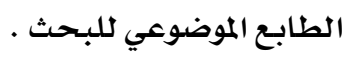

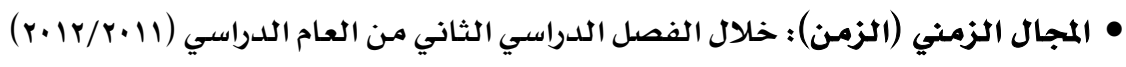
• المجال الجغرايِ (المكان): 
سيتم أجراء تطبيق الأداة على العينة يِّ منطقة جغرافية محددة هي مدينـة الربـاط بـالمغرب

ومدينة نجران بالسعودية .

\section{بعض المفاهيم الخاصة بالدراسة باسعةد}

الثائل والملدير

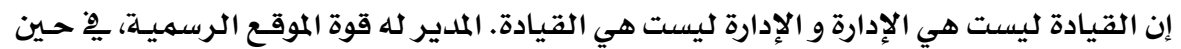

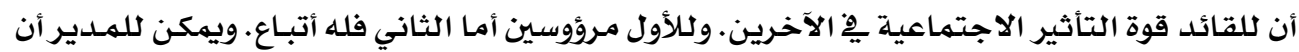

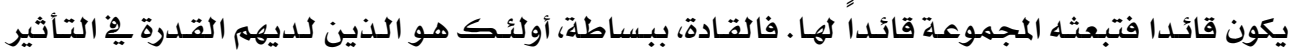

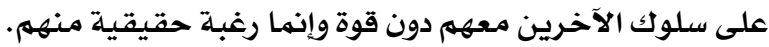

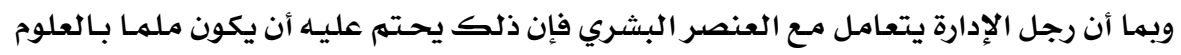

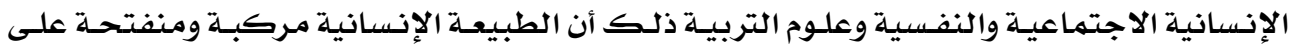

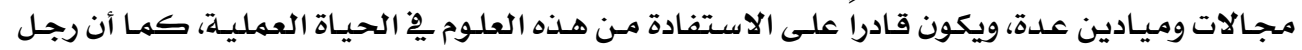

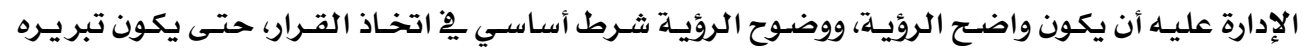

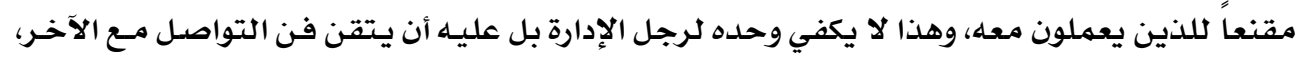

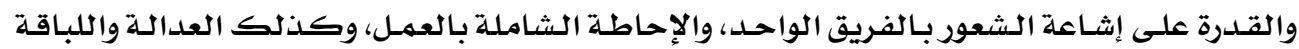

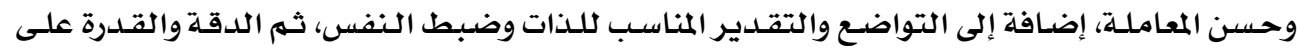
التنظيم، والحماس والابتكار.

مفهوم القيادة :

يظل مفهوم القيادة ملتبساً، حتى أن البعض يفضل إطلاق لفظة " القيادة الإداريـة " على مـا

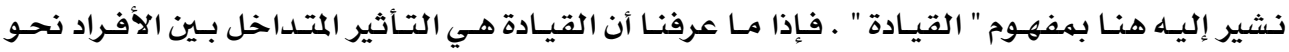

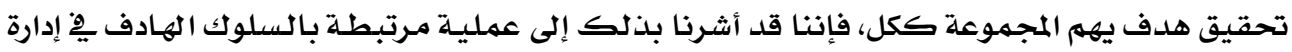

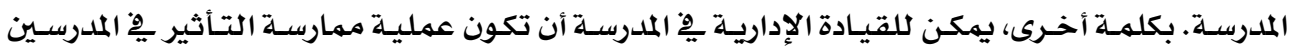

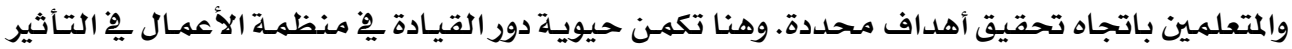

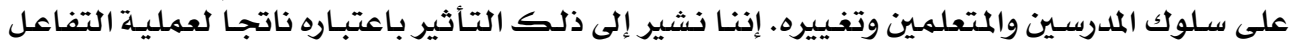

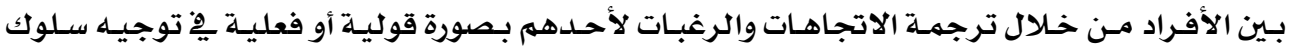

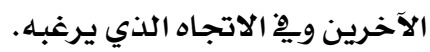

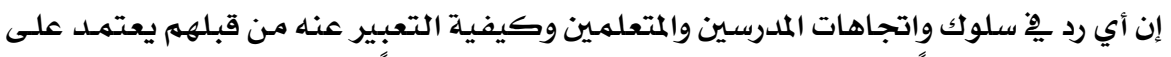

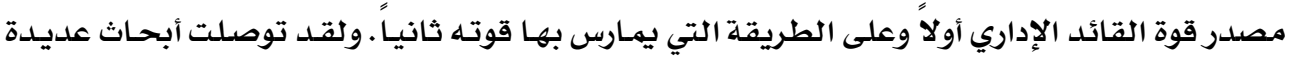

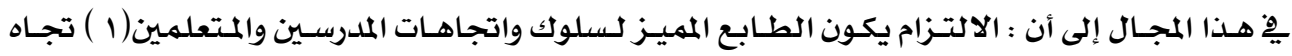

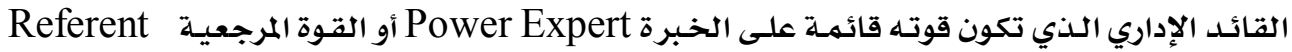

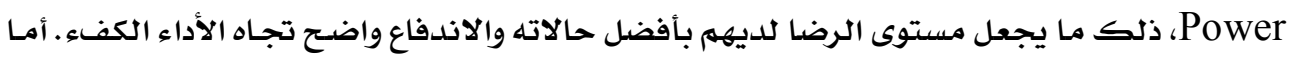

$$
1 \text { نواف بن سفر بن مفلح العتيبي، ^... }
$$




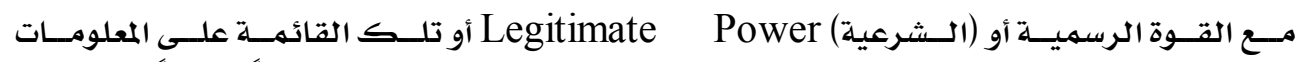

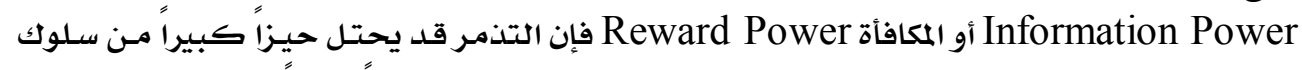

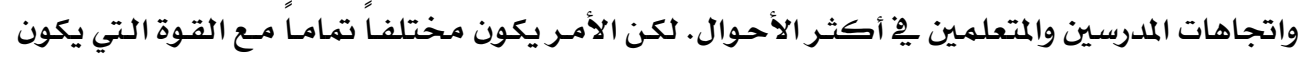

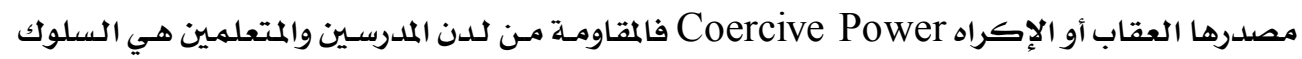

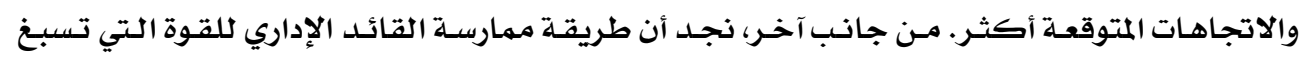

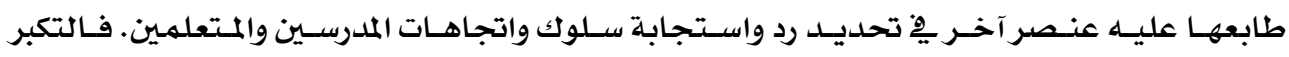

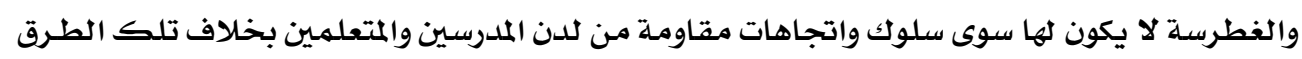

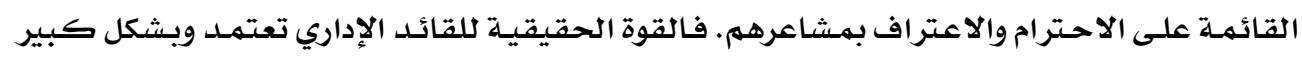

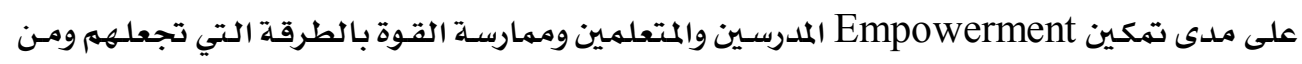

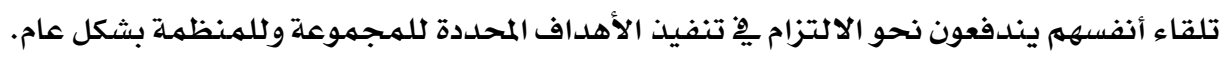

\section{الأساس النفسي للقيادة}

إن دور القيادة التربوية ِِِ حقب التقشف ِِّ ضوء علم النفس التحفيزي، يستند إلى خمسة

افتراضات تتعلق بالمهنيين وكيفية ارتباطهم بالعمل.

مبادئ القيادة:

من الافتراضات سالفة الذكر، يمكنني استخلاص مبادئ قيادية محددة من شأنها المحافظة

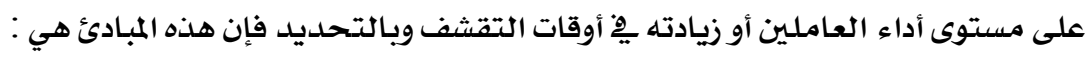

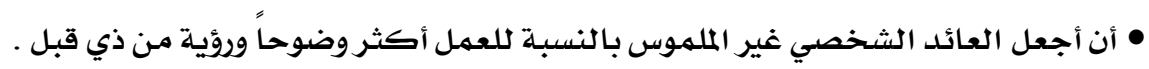

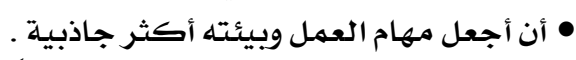

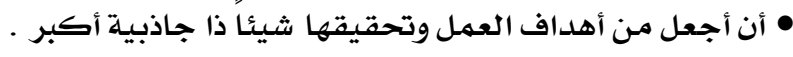

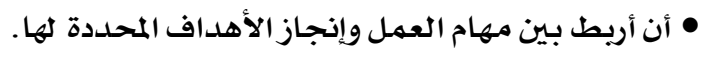

أهم سمات الشخصية القيادية :

• يتميز بالصحة النفسية العالية .

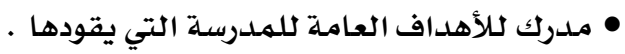

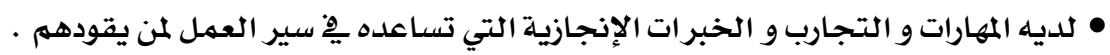

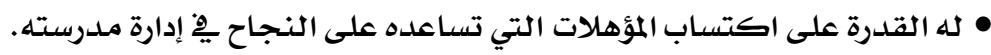

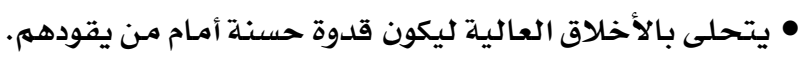

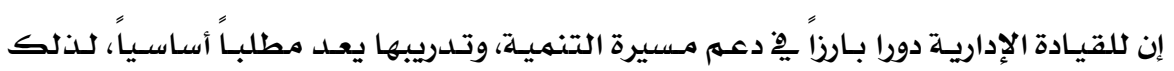

يجب دعم المواقف التدريبية بأنشطة عملية هادفة متفقة والاحتياجات التدريبية للفئة المستهدفة دورة (1 ).

نورة بنت عبد الله الفايزو بهية بنت عبد الحميد أبو علي،مقدمة لترجمة كتاب تدريب القيادات، إليزابيث كرستوفرو

لاري سميث،ص 9.

1. 


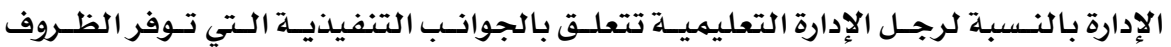

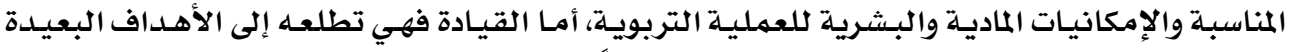

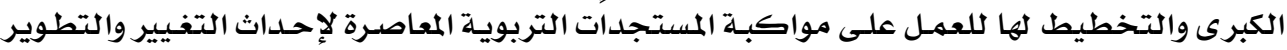

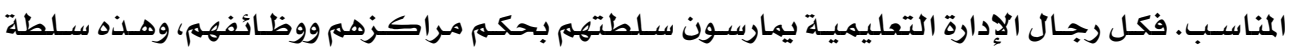

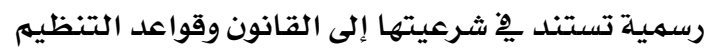

أما القيادة فيستمدها رجل الإدارة التعليمية من خلال مكانته بين العـاملين معـه التي تجعل التهل

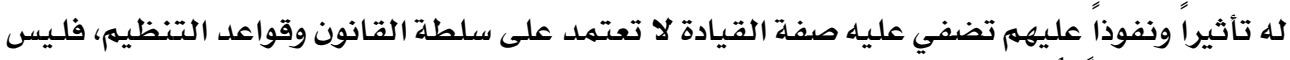

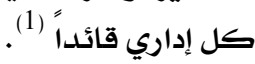
القيادة وأنماطها :

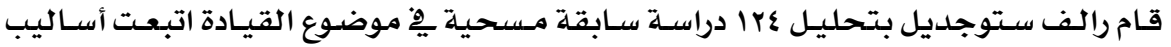

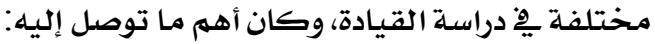

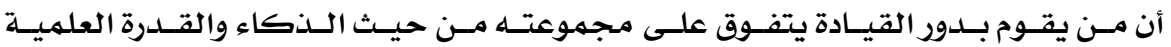

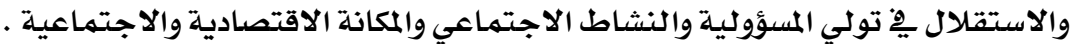
أن الصفات والمهارات المطلوبة يِّ القائد تتوقف إلى درجة كبيرة على متطلبـات الموقف الدي يقوم فيه بلدور القيادة (2).

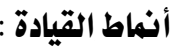
التصنيف الأول : المبكر لماكس ويبر • القيادة التقليدية : يتوقع القائد مهن معه الطاعة المطلقة والولاء الشخصي له، ويعتمـد المثل

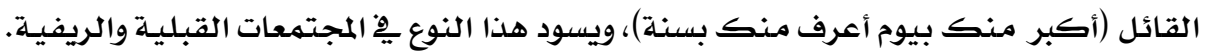

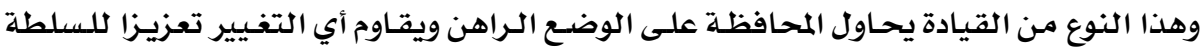

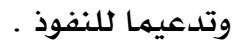

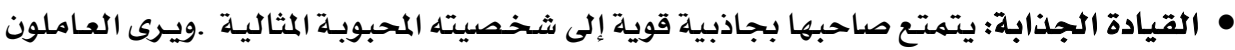

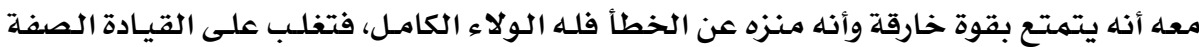

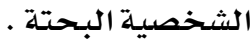

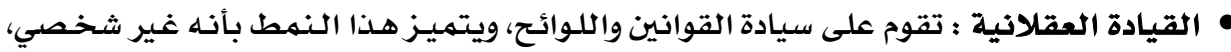

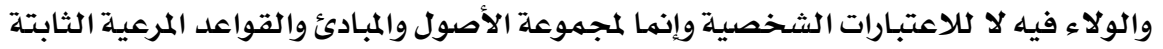

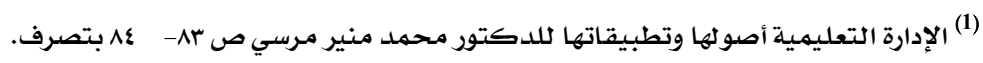

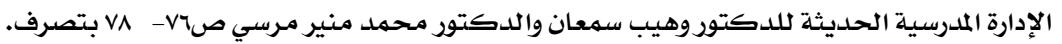

(2) Stogdill ,R.: Personal Factors Associated with leadership. Survey of the Leadership. Journal of Psychology vol. 25 page 35-71. 


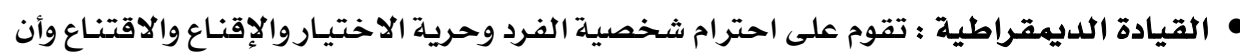

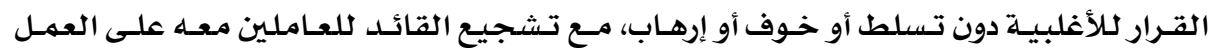

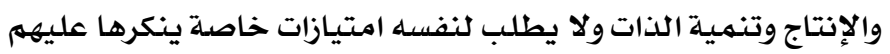

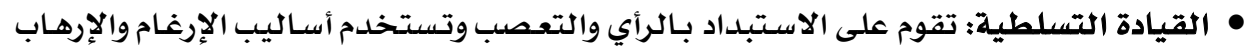

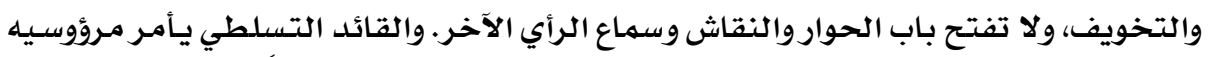

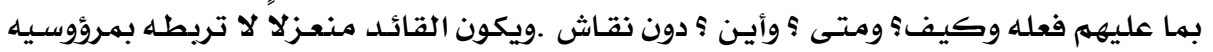

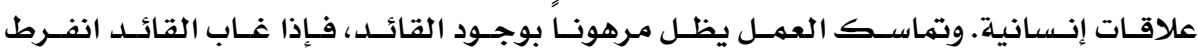

$$
\text { عقد المجموعة . عات إنانة. }
$$

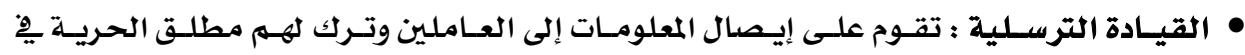

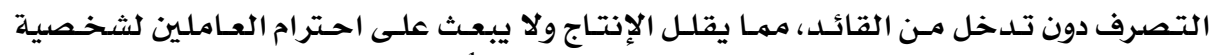

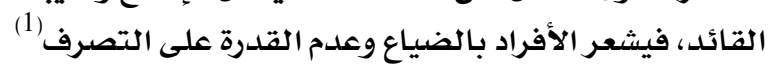

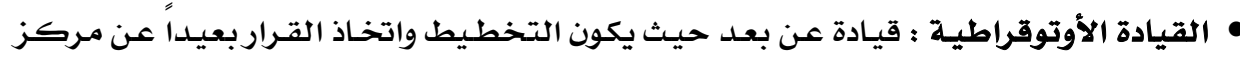

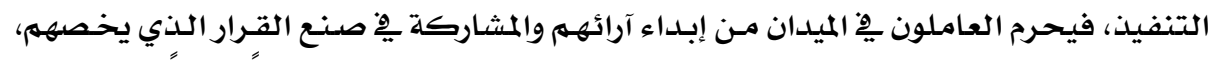

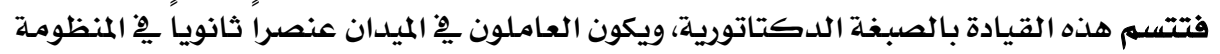

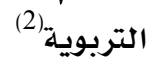

\section{القيادة التزبوية بين الأصالة والمعاصرة :}

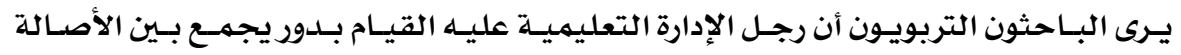

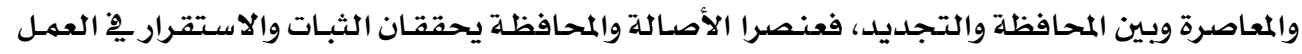

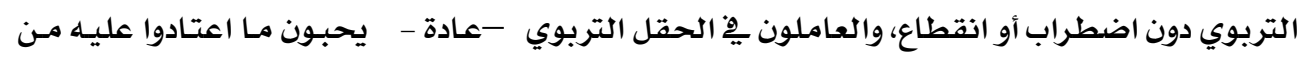

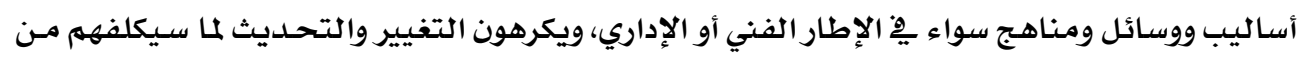
جها وعناء.

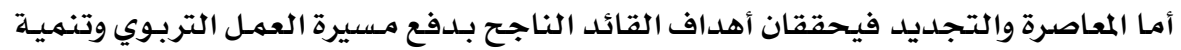

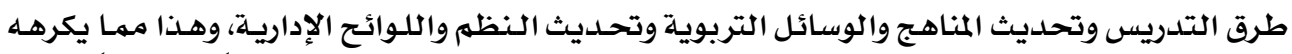

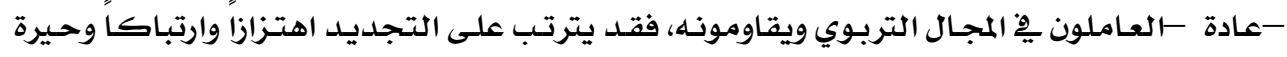

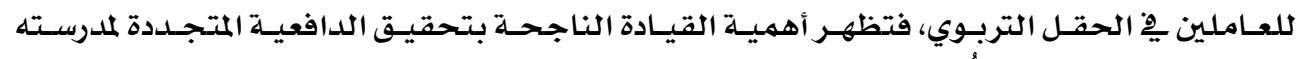

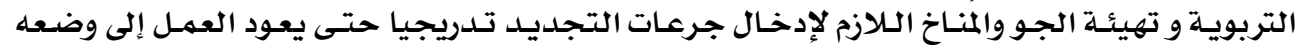

(1) الإدارة التعليمية أصولها وتطبيقاتها للدكتور محمد منير مرسي ص AV- .9 بتصرف.

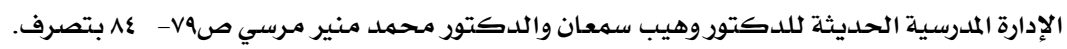

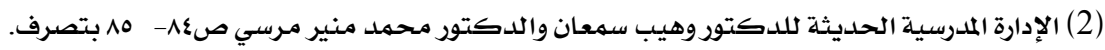

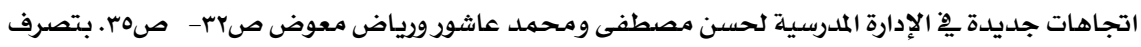




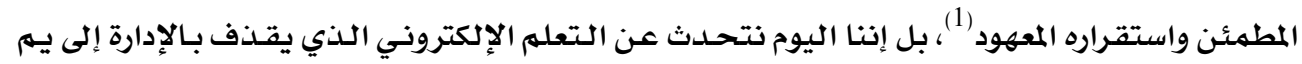

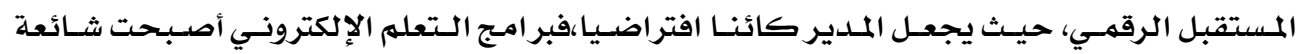

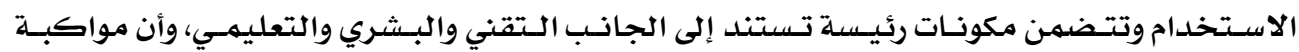

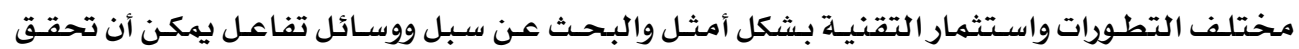

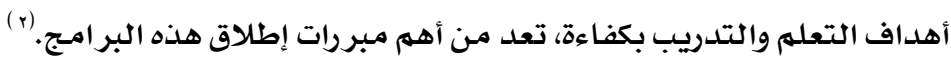

\section{تطور مفهوم القيادة التربوية :}

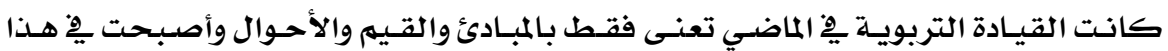

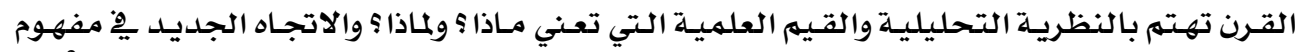

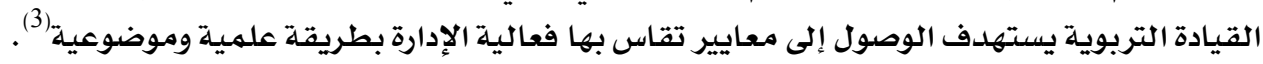

نظريات الإدارة التربوية:

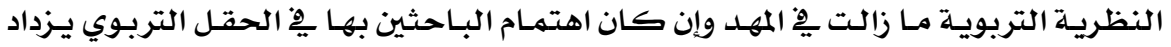

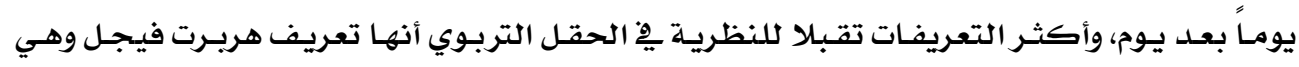

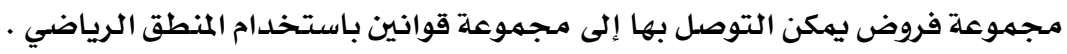

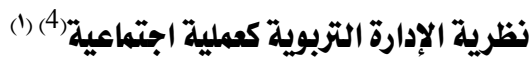
نموذج جيتزيز مبنى النظرية أن الإدارة التربويـة تسلسل هرمسي للعلاققات الوظيفيـة بـين الرؤسـاء والمدرسـين

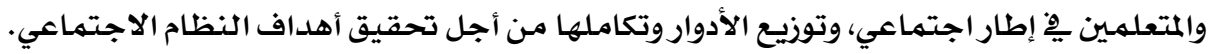

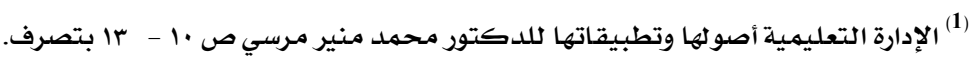

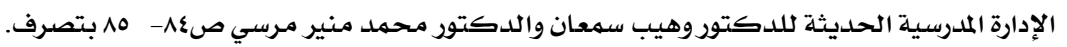

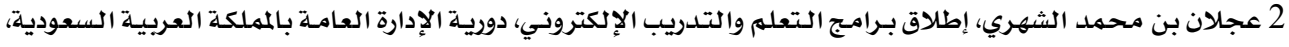


نموذج جيتزلز لليعد التنظيمي المعياري والبعد الشخصي للسلوك الاجتماعي البعد التنظليمي أو المعياري

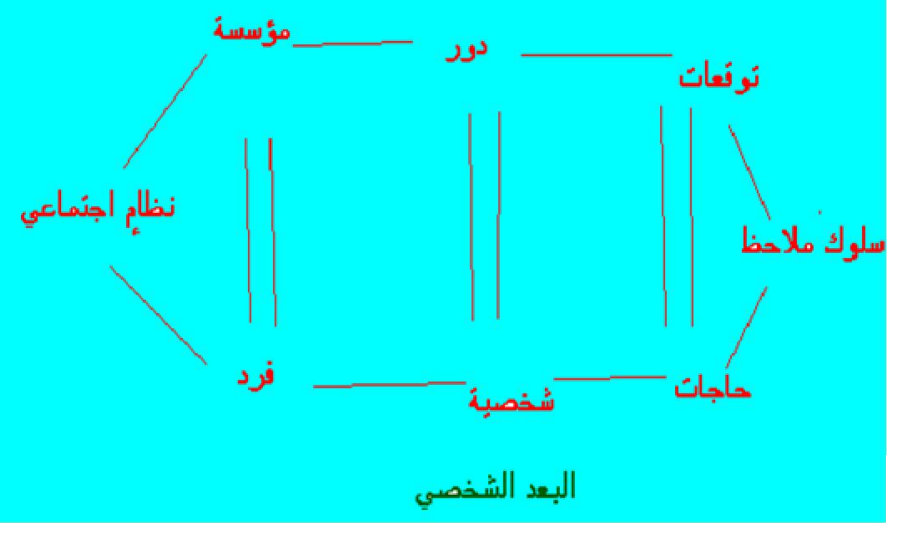

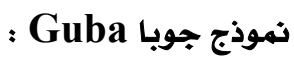

مبنى النظرية أن القائد التربوي يعمل كوسيط بين مجموعتين من القوى الموجهة للسلوك

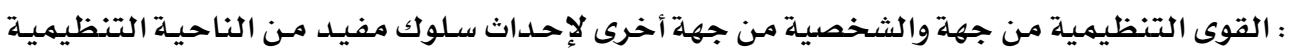

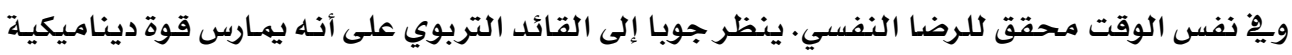

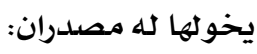

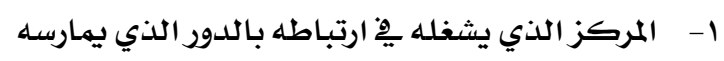

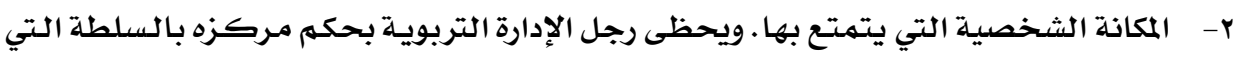

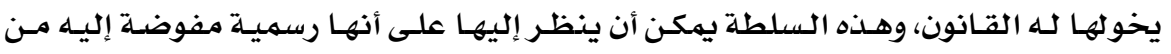

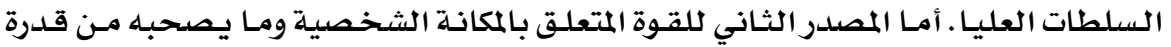

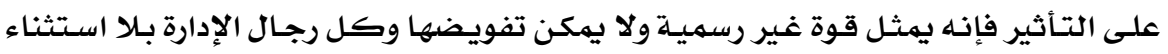

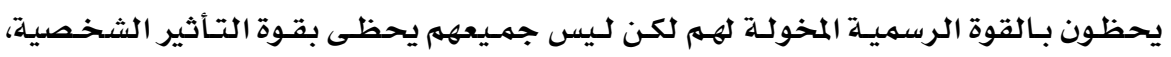

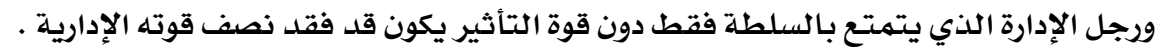

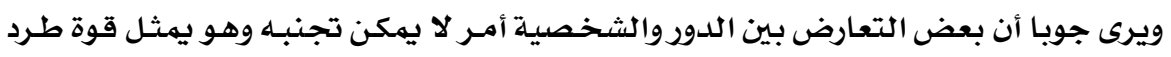

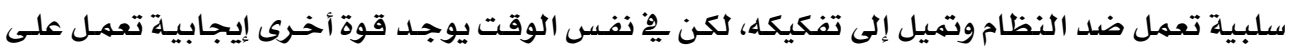

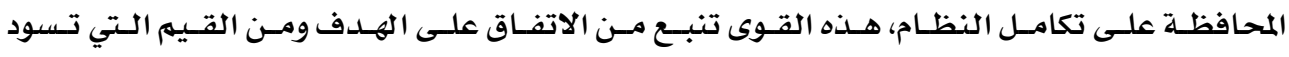
المدرسة التربوية . 


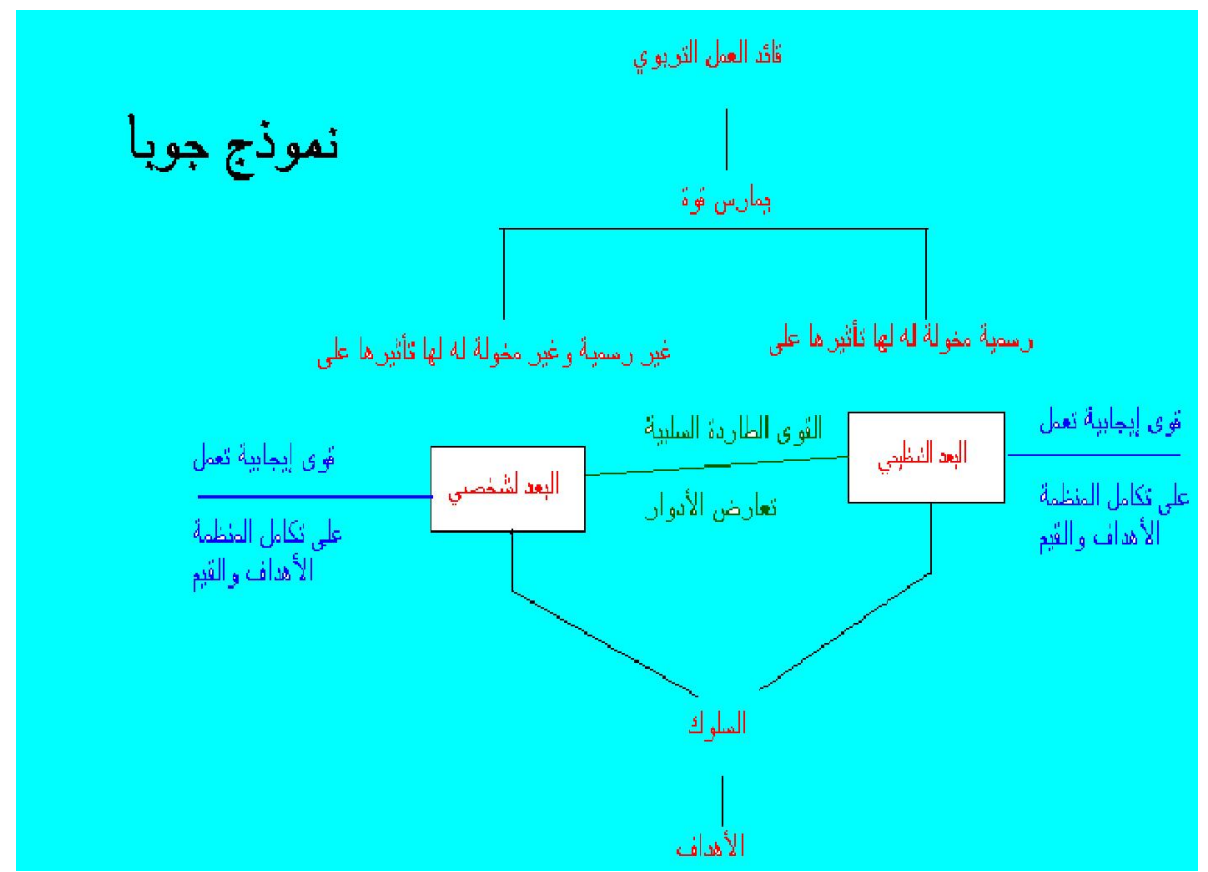

T. Parsons(1) نظرية تالكوت باسونز

مبنى نظرية بارسونز على أن الإدارة التربوية متفرعة من المجتمـع الكبير، فتقوم نظريته على

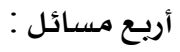

- التأقلم والتكيف مـع مطالب البيئة الخارجية .

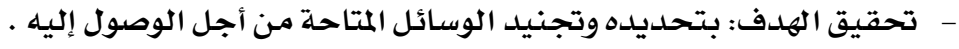

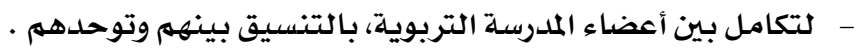

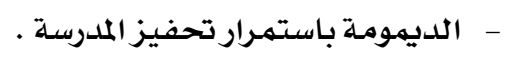

ويميز بارسونز بين ثلاثة مستويات وظيفية يِّ التركيب الهرمي للمدرسـة التربوية

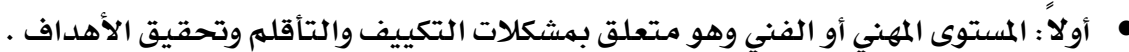

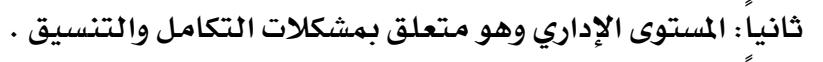

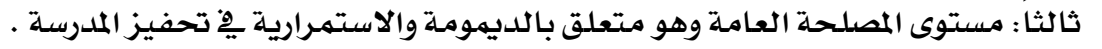

(1) الإدارة التعليمية أصولها وتطبيقاتها للدكتور محمد منير مرسي ص Or - Or - بتصرف. 


\section{نظرية الإدارة التربوية كعملية اتخاذ للقرار(1)}

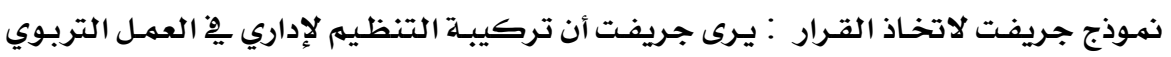

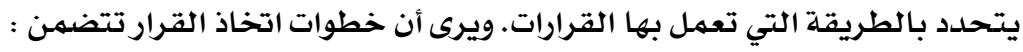

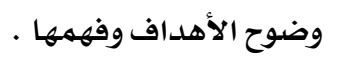

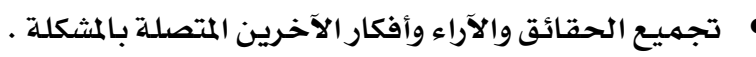

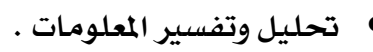

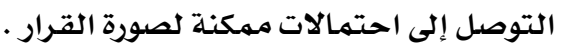

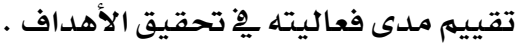

تصل عملية اتخاذ القرار إلى ذروتها بتغليب أحد الاحتمالات واختباره على أنه الأنسب(؟ ) .

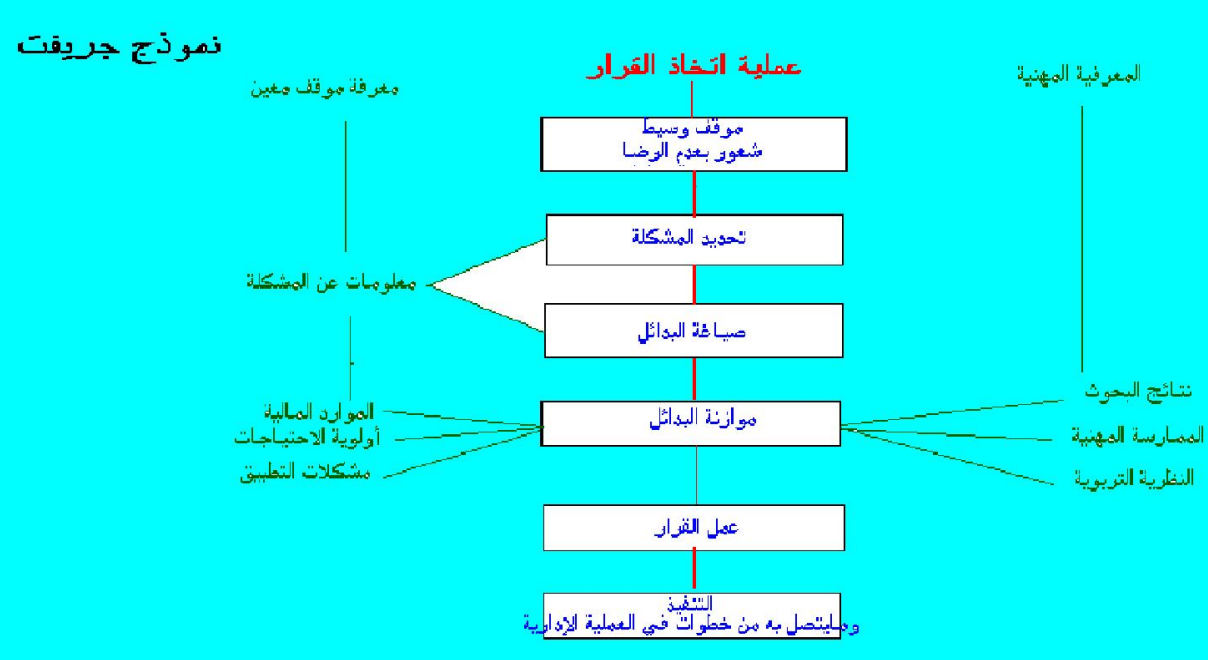

عندما يتخذ القرار تبدأ مرحلة وضع برنامـج للتنفيذ بالإمكانيـات ولوسـائل الماديـة والبشريـة

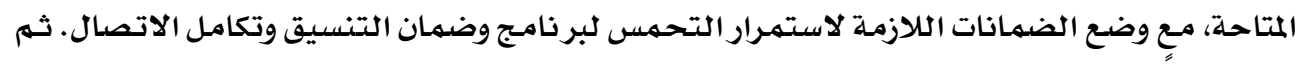
تأتي أخيراً مرحلة التقوضع الفوضيم.

(1) الإدارة التعليمية أصولها وتطبيقاتها للدكتور محمد منير مرسي ص

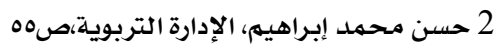


نظرية الإدارة التربوية كوظائف ومكونات(1)

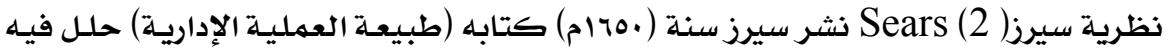

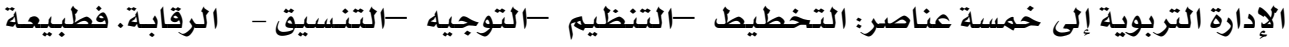

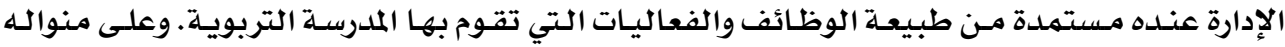

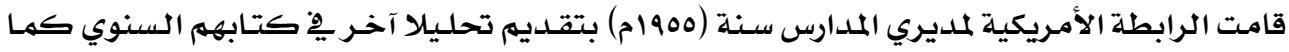

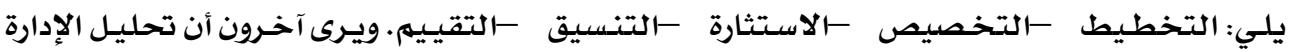

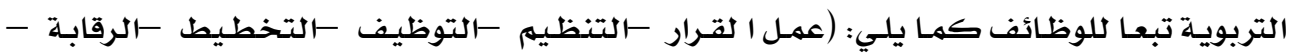

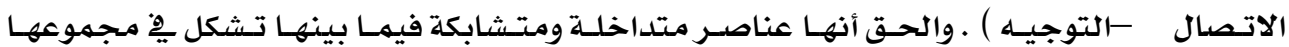

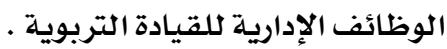

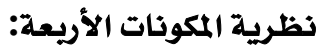

يرى هالبين أن الإدارة التربوية لها أريعة مكونات : (العمل - المدرسية التربويـة - العـاملون القائد التربوي )

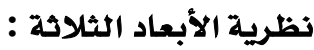

تعتبر من الجهود المبكرة ِِِ ميدان التتظير للعمل التربوي ولها ثلاثة عوامـل : (الوظيفـة رجل الإدارة - الجو الاجتمعاعي)

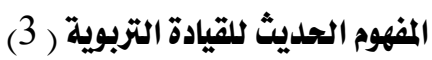

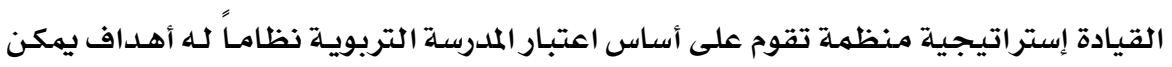

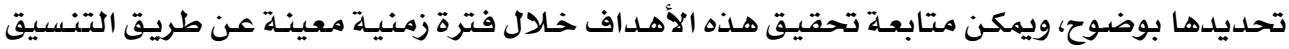

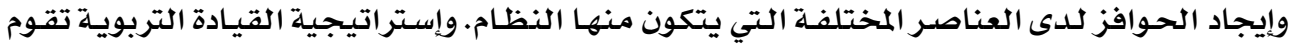

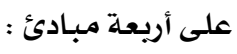

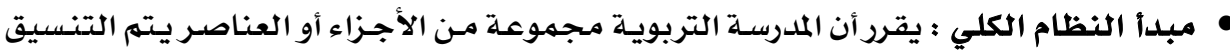

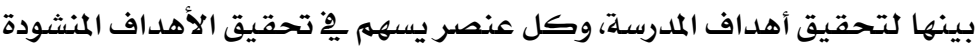

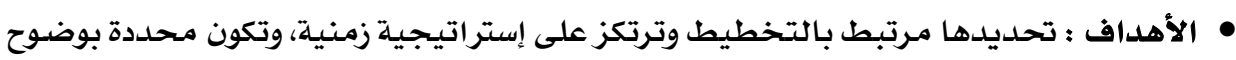

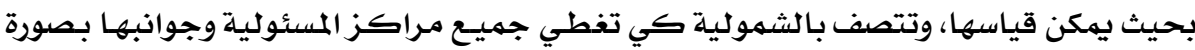

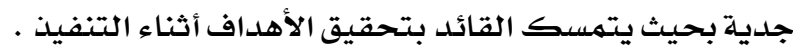

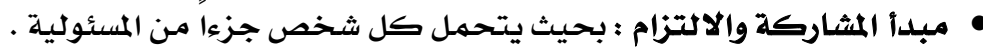

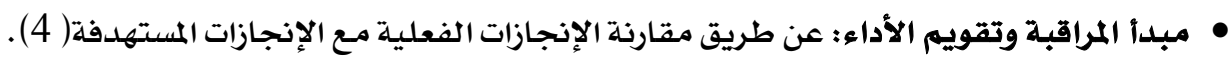

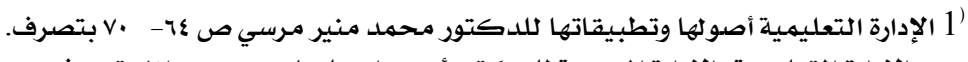

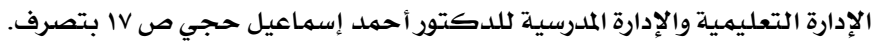
(2) Sears J The Nature Of the Administration process (3) الإدارة التعليمية أصولها وتطبيقاتها للدكتور محمد منير مرسي ص ا0- • ب بتصرف.

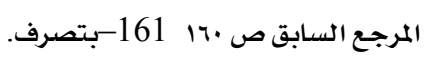




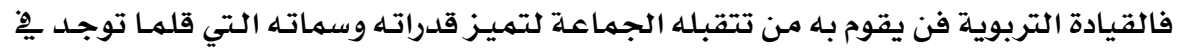

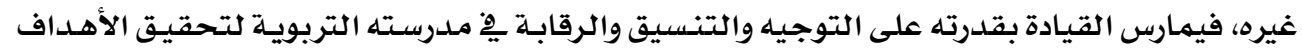

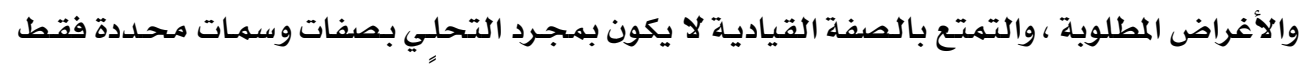

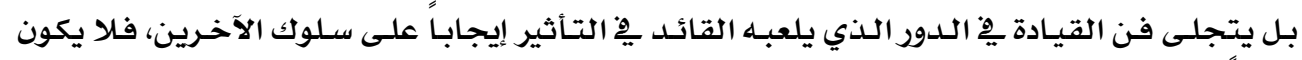

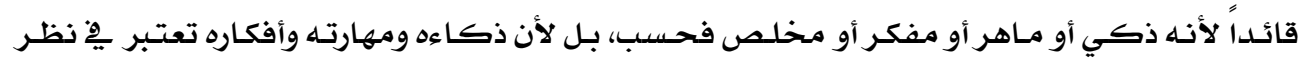

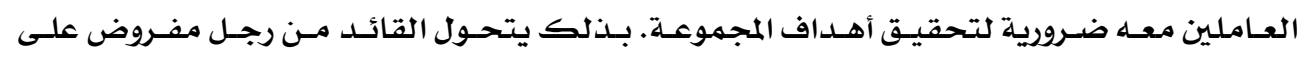

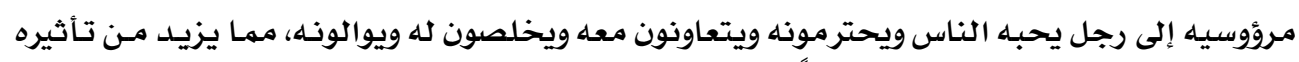

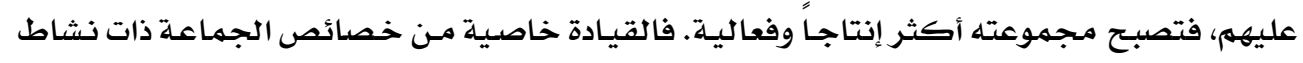

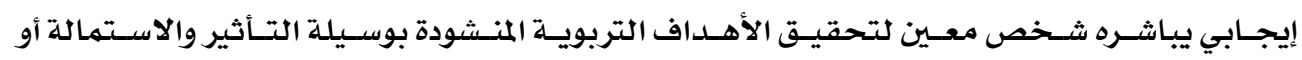

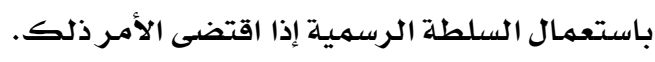

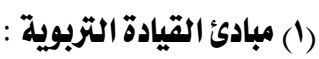

نستعرض مبـادئ القيـادة التربويـة مـن خـلال إطـارين ذظـيـين معـروفين بإطـار فـايول وإطـار

موني :

Monney's Framework موني :

يقوم إطار موني على أسس تنظيمية ثلاثة:

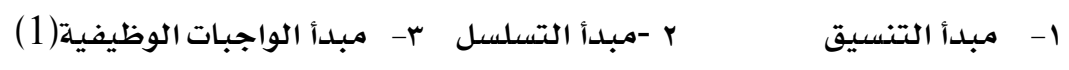

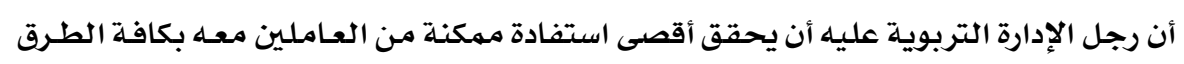

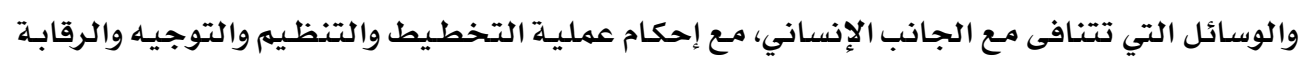

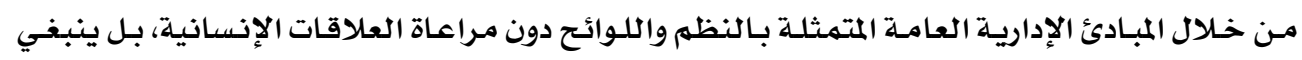

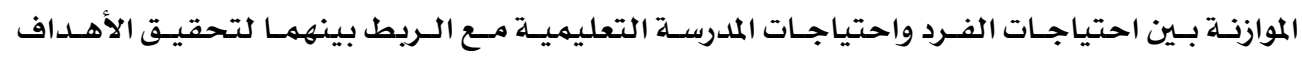
المنشودة(2) .

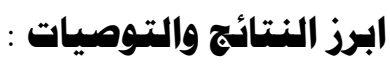

ملخص نتائج الدراسة :

1) أظهرت النتائج أن معدلات عبارات بعد المبادرة والاهتمام بالعمل من أبعاد ( س.اه) وفق مقياس

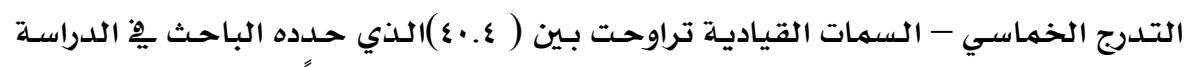

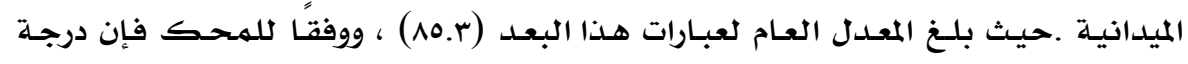

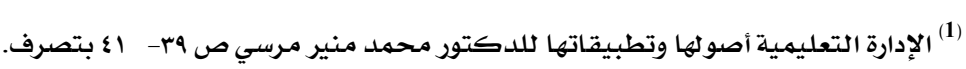

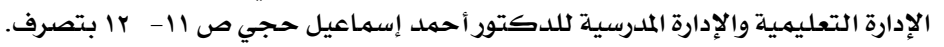

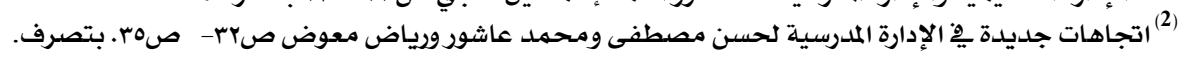

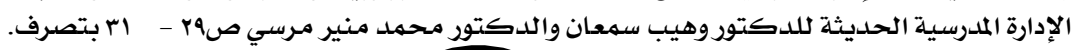


ممارسة بعد المبادرة والاهتمام بالعمل من السمات القيادية لدى مديري المدارس الثانوية من

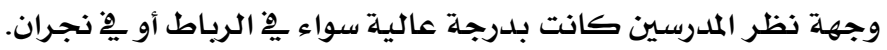

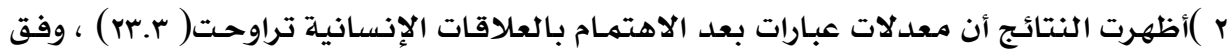

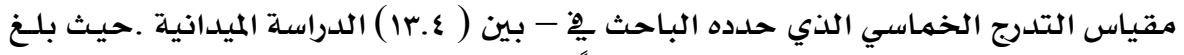

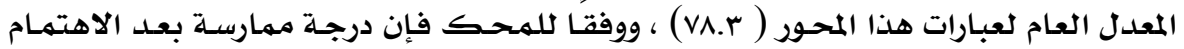

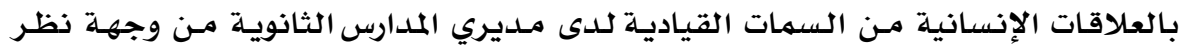

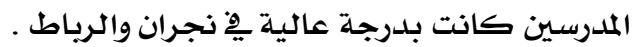

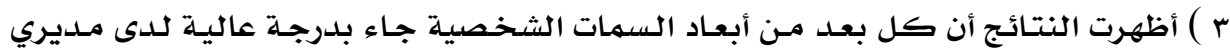

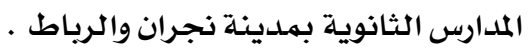

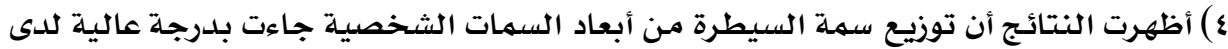

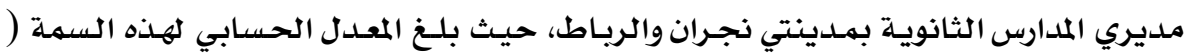

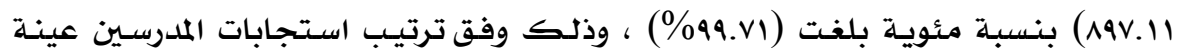

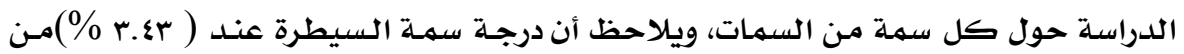

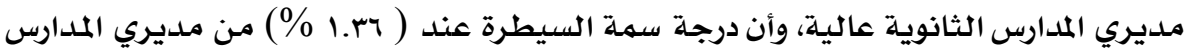

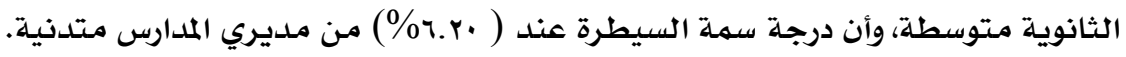

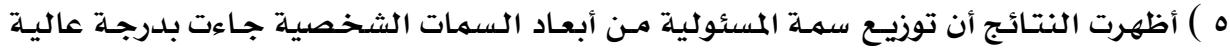

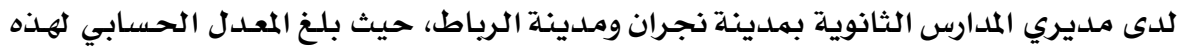

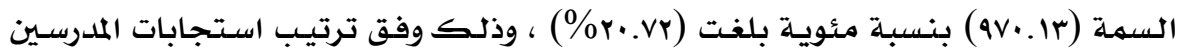

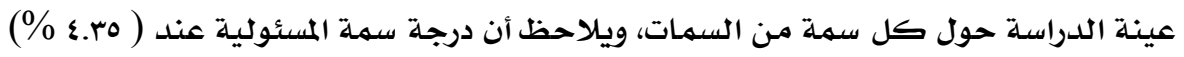

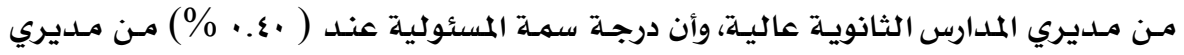

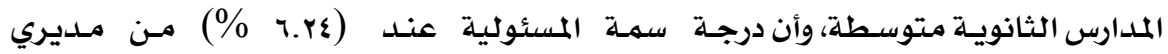
المدارس متدنية.

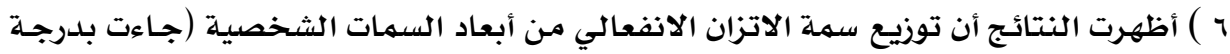

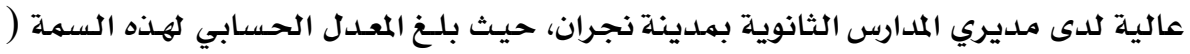

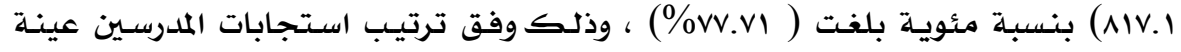

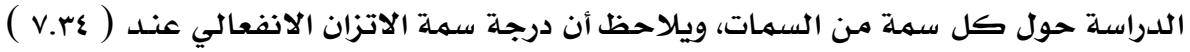

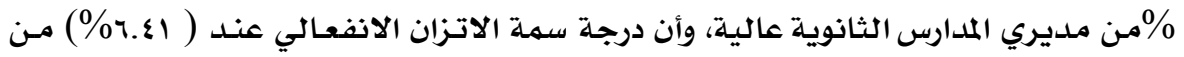

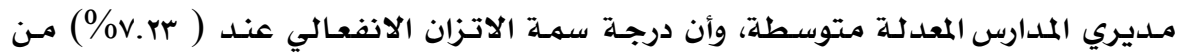
مديري المدارس متدنية.

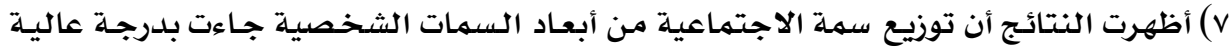

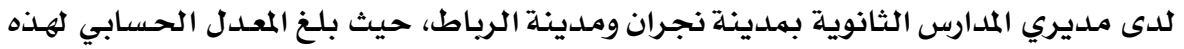

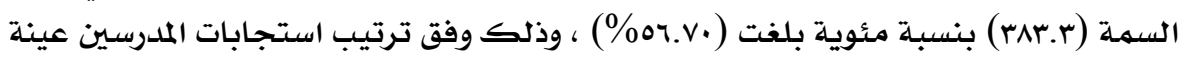

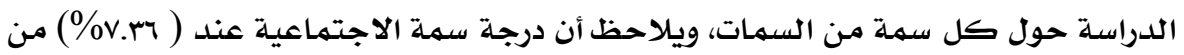




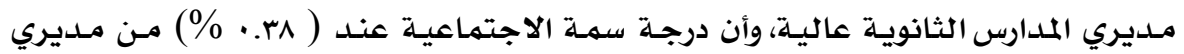

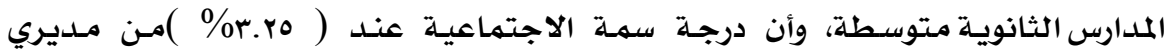
المدارس متدنية.

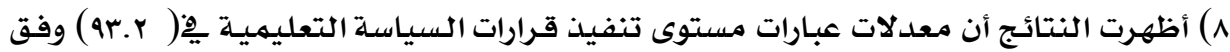

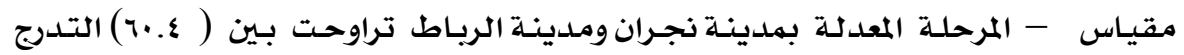

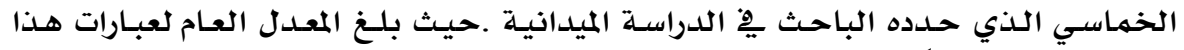

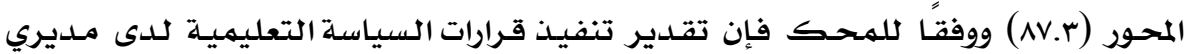

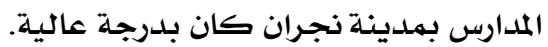

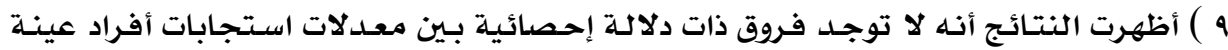

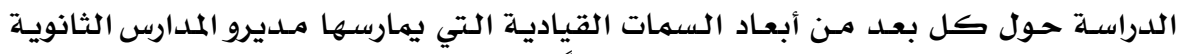

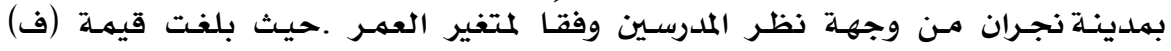

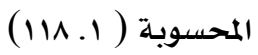

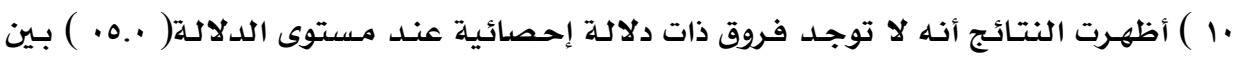

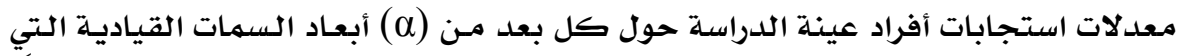

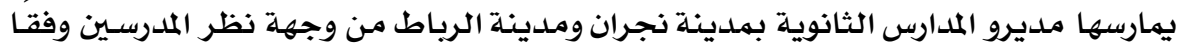

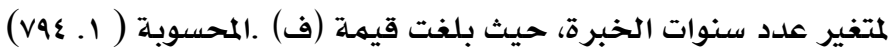

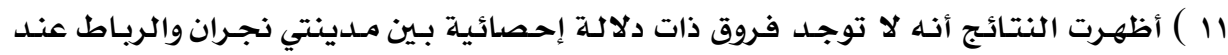

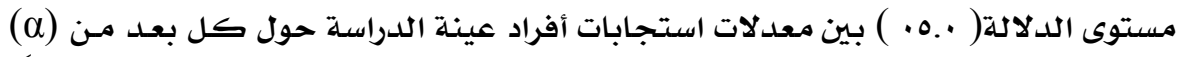

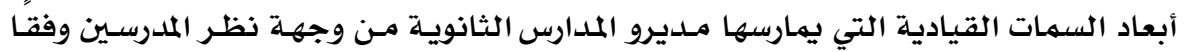

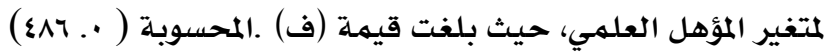

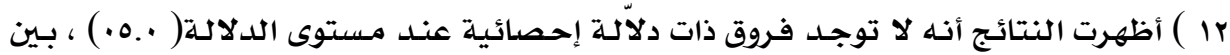

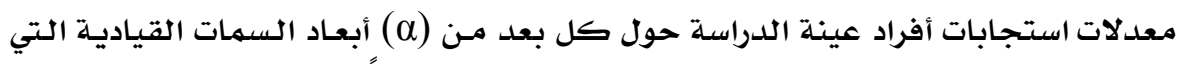

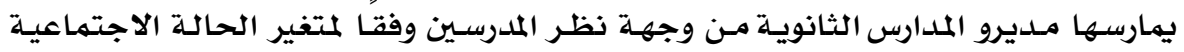

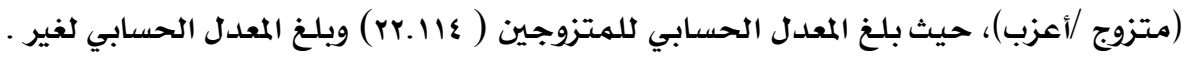

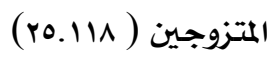

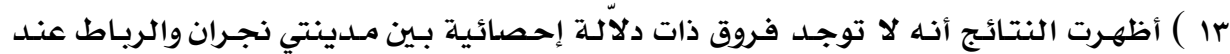

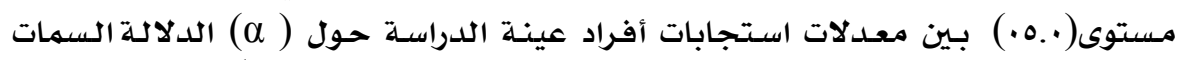

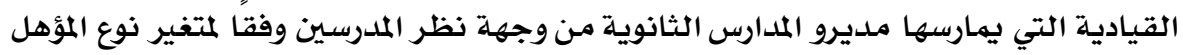

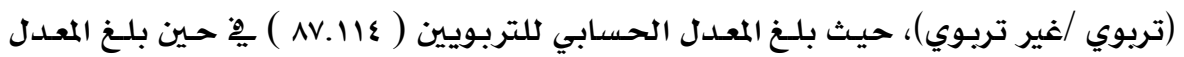

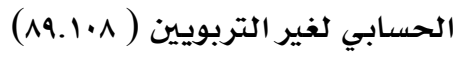

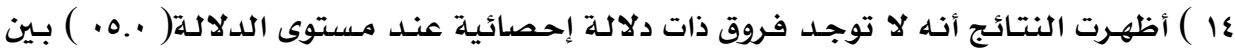

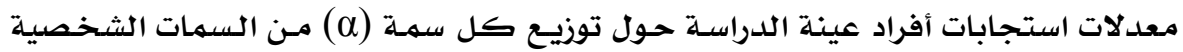


لمديري المدارس الثانوية بمدينة نجران من وجهة نظر المدرسين وفقا لمتغير العمـر، حيث بلغت

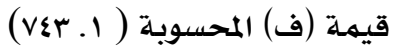

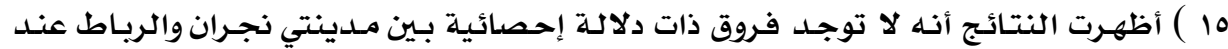

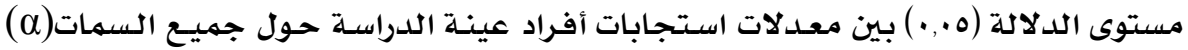

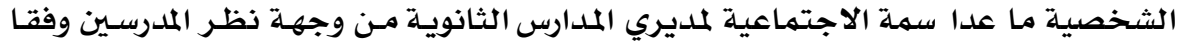

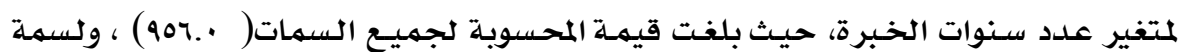

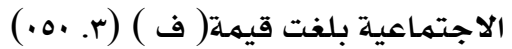

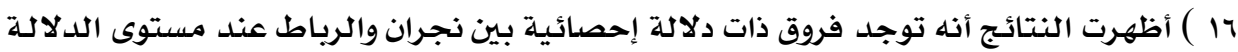

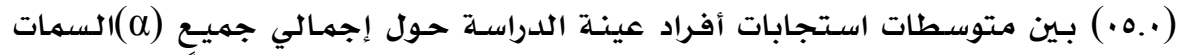

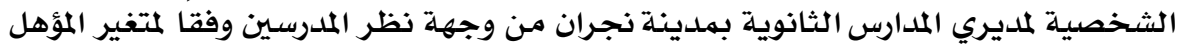

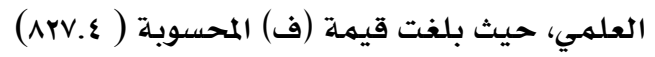

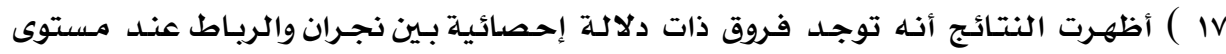

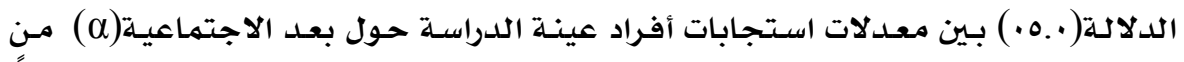

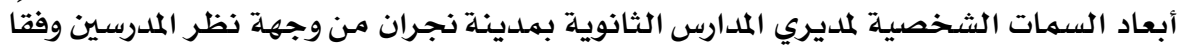

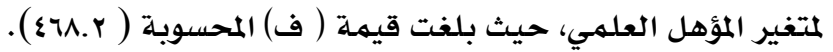

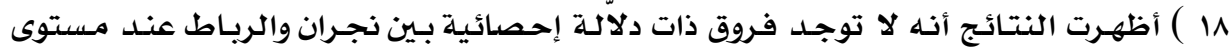

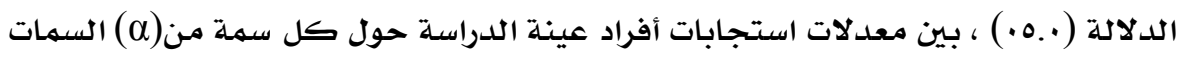

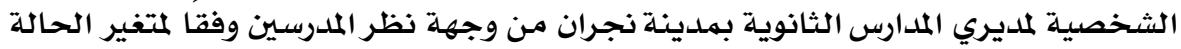

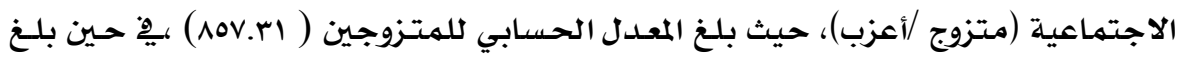

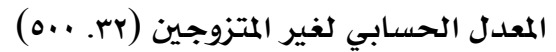

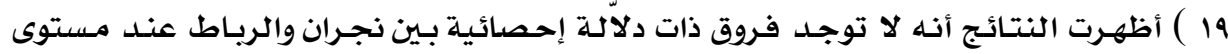

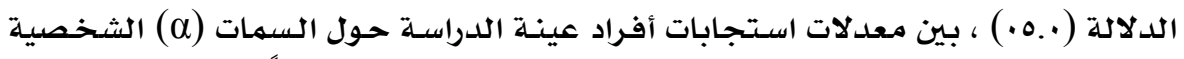

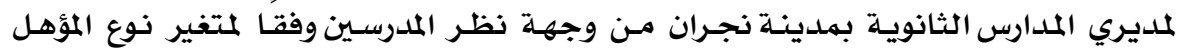

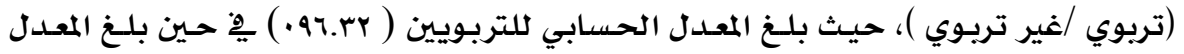

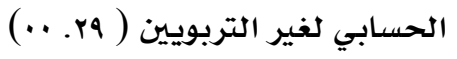

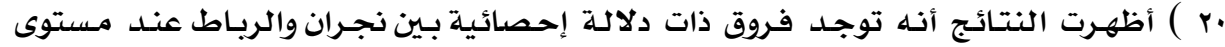

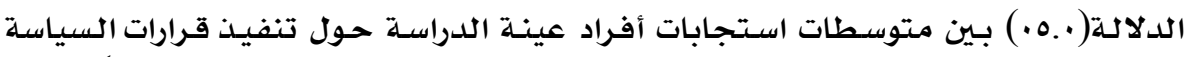

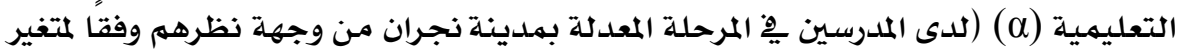

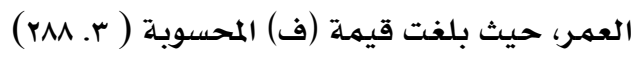

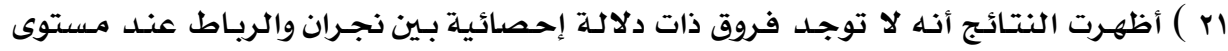

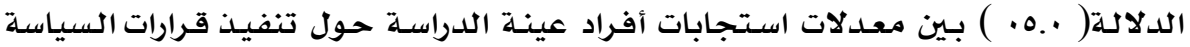

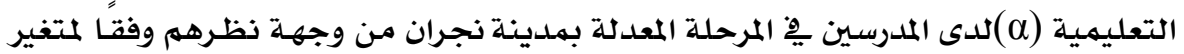

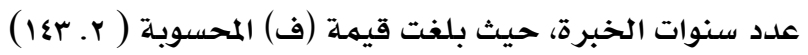




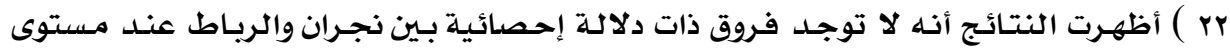

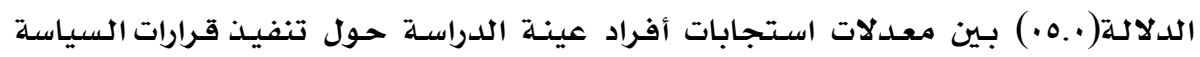

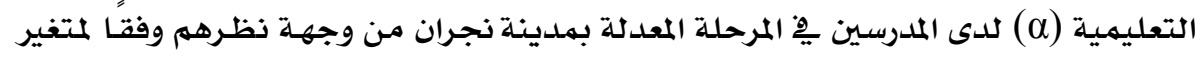

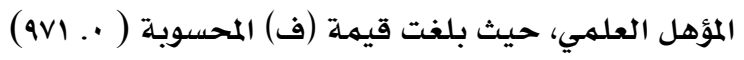

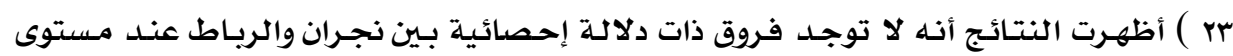

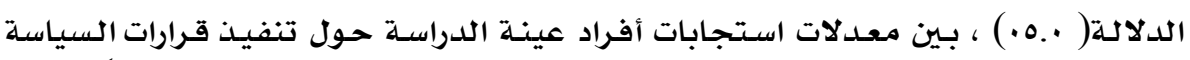

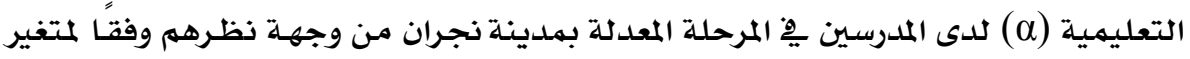

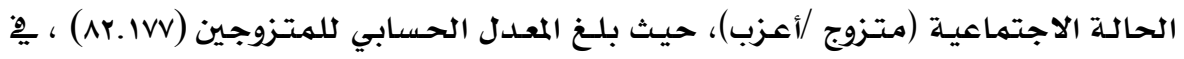

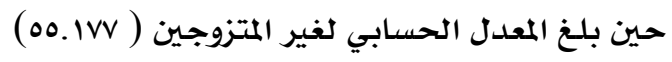

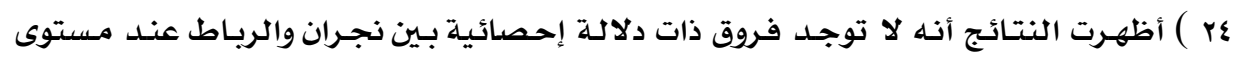

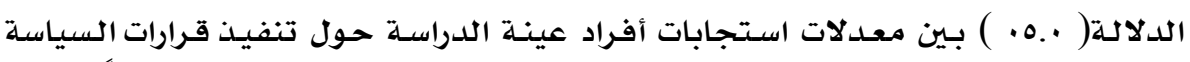

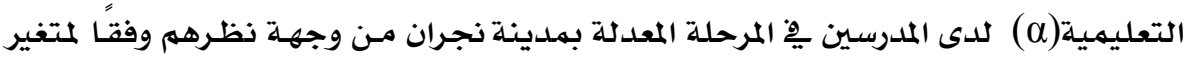

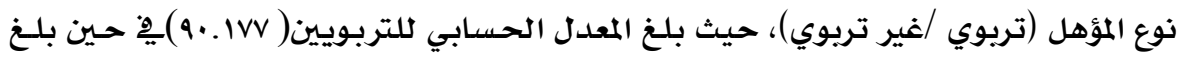

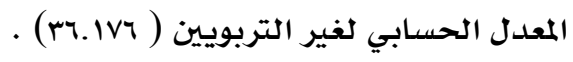

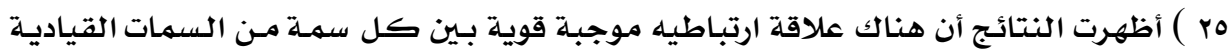

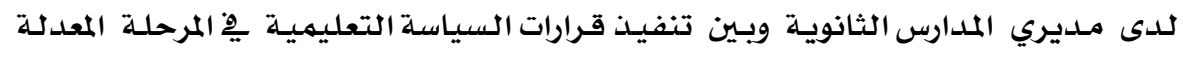

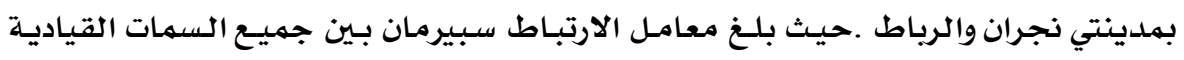

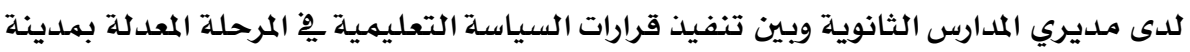

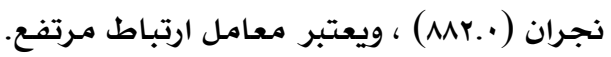

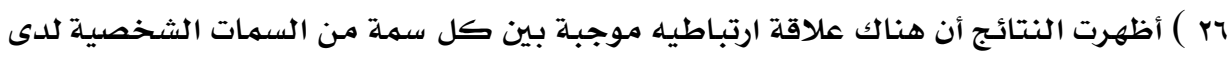

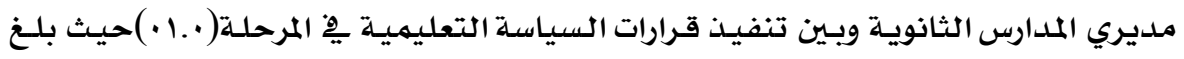

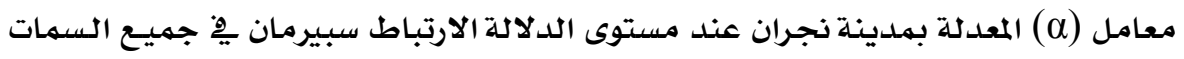

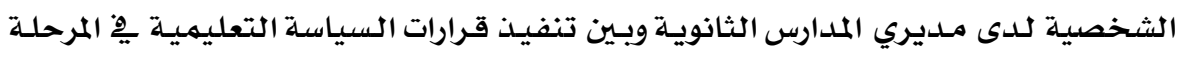

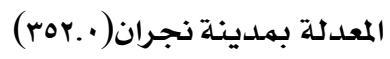

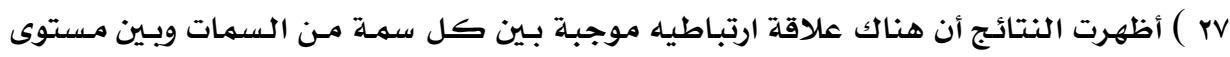

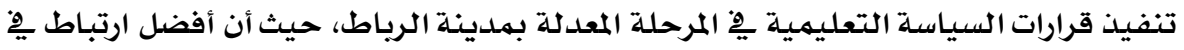

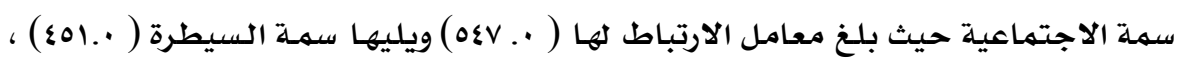

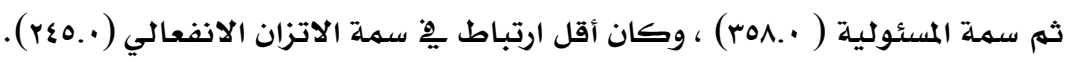

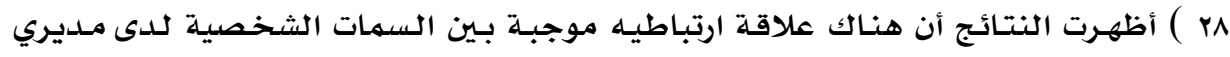

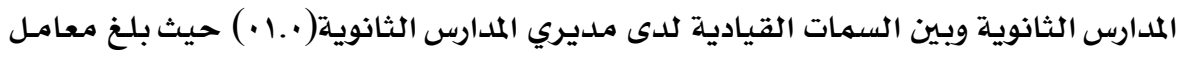

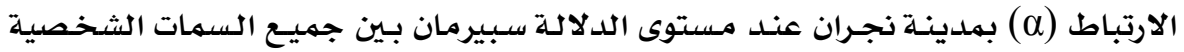

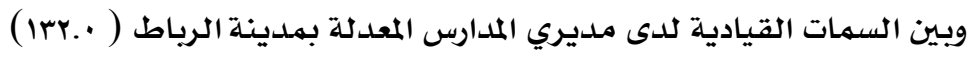


و ) أظهرت النتائج أن هناك علاقة ارتباطيـه موجبـة كل سمـة مـن السمات وبـين السمات

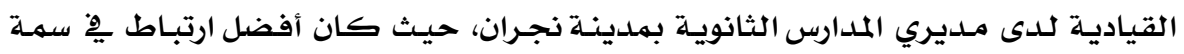

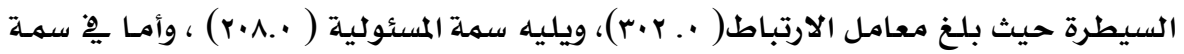

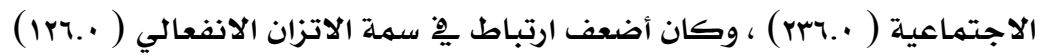

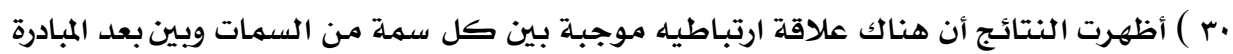

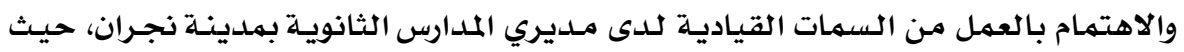

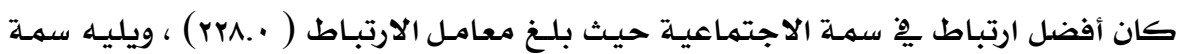

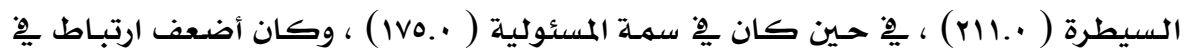

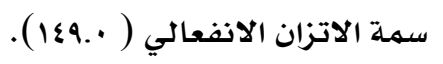

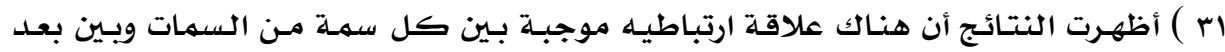

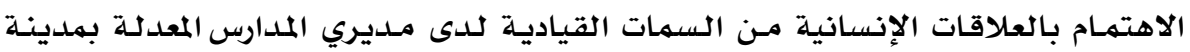

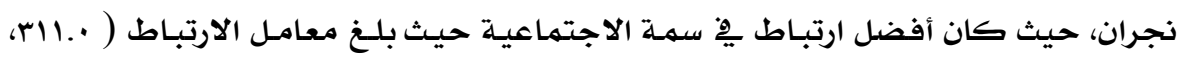

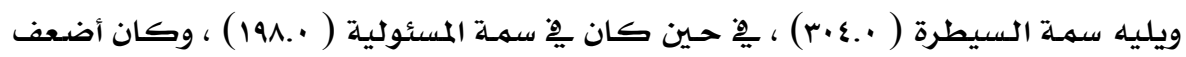

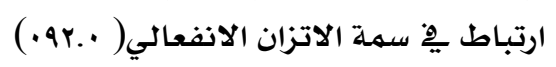

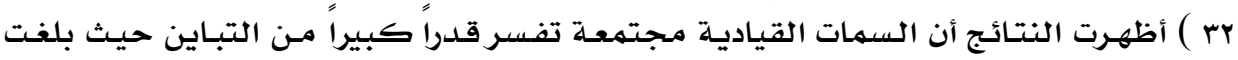

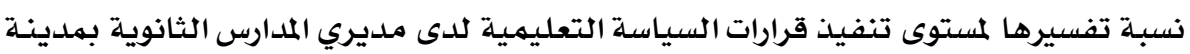

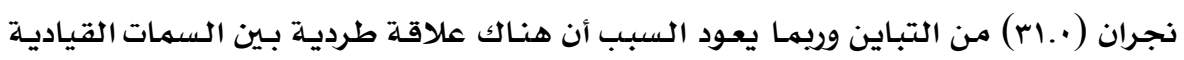

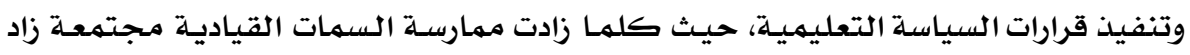

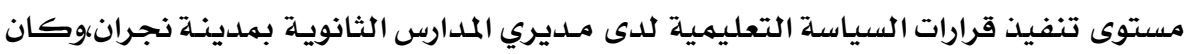

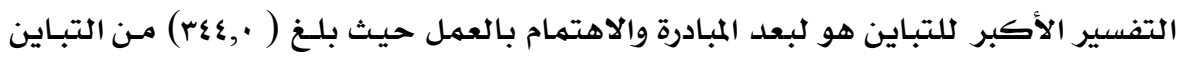

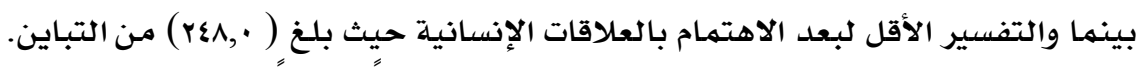

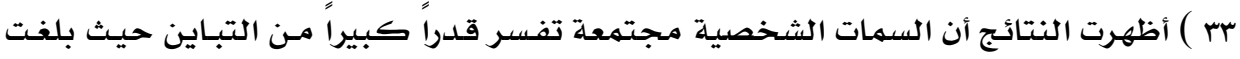

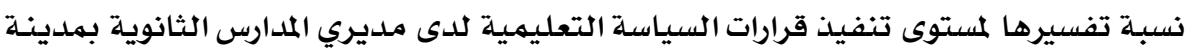

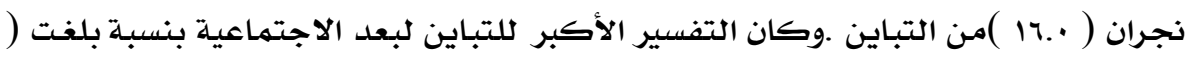

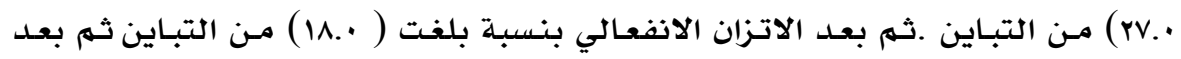

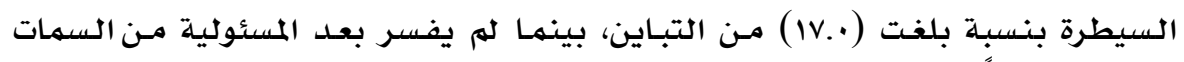

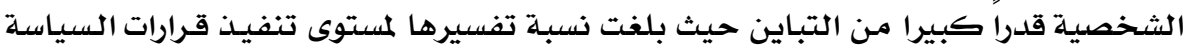

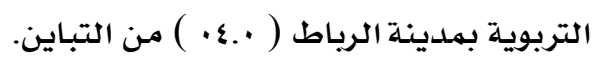

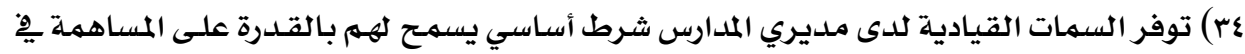

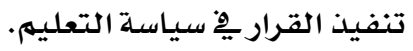

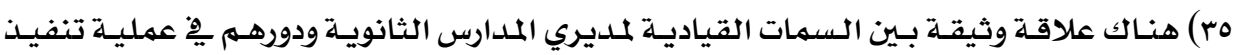
القرار فِّ سياسة التعليه. 
بناء ع على النتائج السـابقة التي توصلت إليها الدراسـة يهكن تقديهم عدد مـن التوصيات

$$
\text { وهي كما يلي : }
$$

ا ضصرورة الممارسـة على الدرجـة العالية للسمات القيادية والسمات الشخصية لدى مـديري المدارس

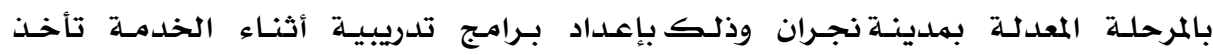
صفة الاستمرارية.

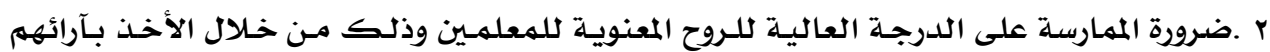

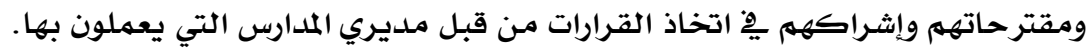

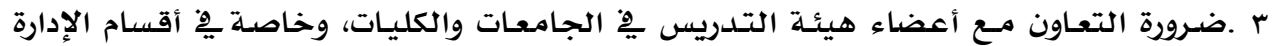

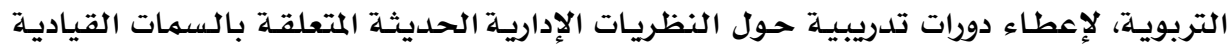

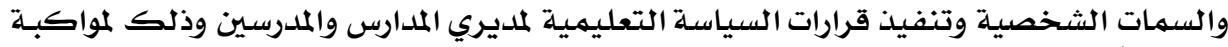

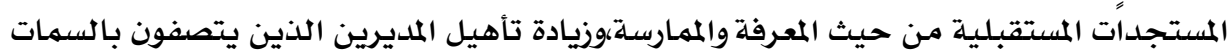

الشخصية المتدنية.

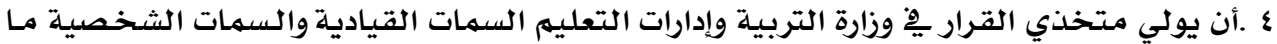

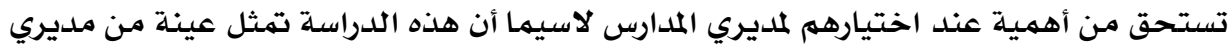

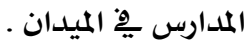

ه .الاستفادة مـن أداة الدراسـة الحاليـة ِِّ تقويم السمات القياديـة والسمات الشخصية لمديري

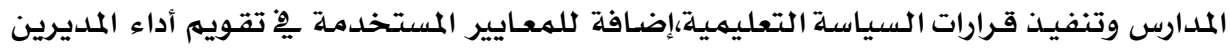
والمدرسين. 7 . السماح للمعلمـين بمواصلة دراساتهم العليا دون عوائق لأن المدرسين ذوي المؤهلات العليـا كانوا

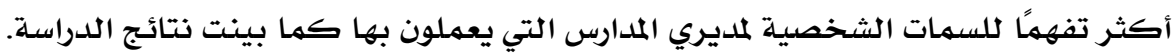

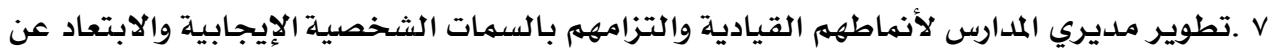

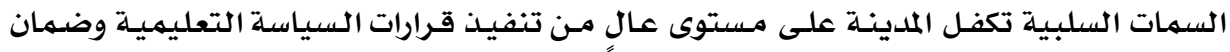
مستوى كاف من الإنتاجية يفي العمل.

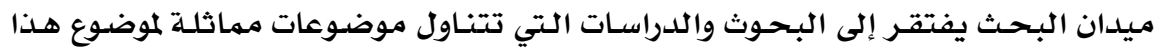

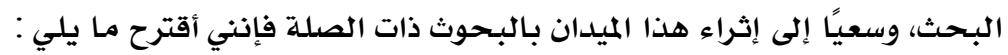

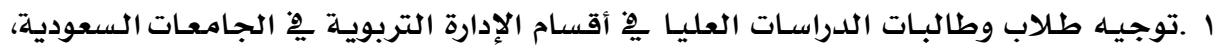

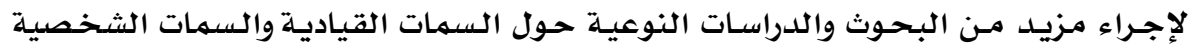

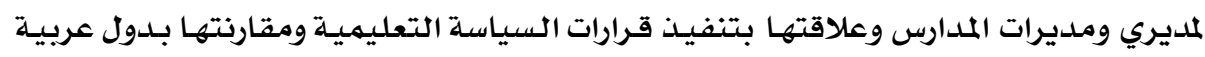

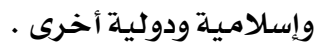




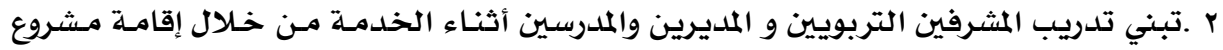

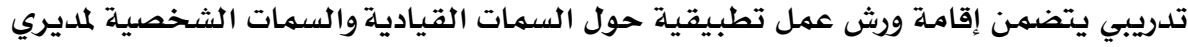
المدارس وعلاقتها بتنفيذ قرارات السياسة التعليمية.

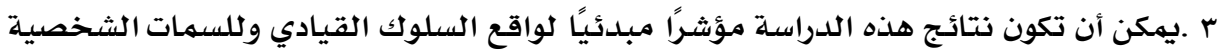

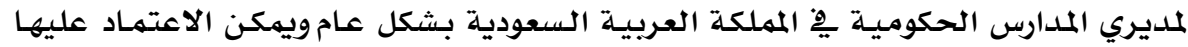

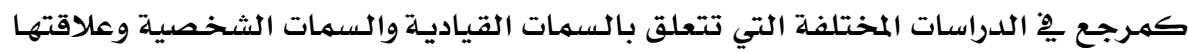

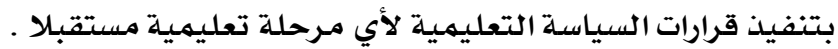

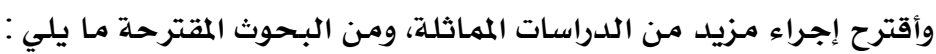

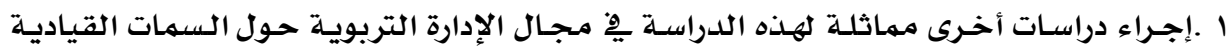

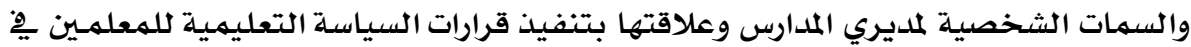
الواقع الميداني يِّ بيئات أخرى من المملكة العربية السعودية ومقارنتها بهذه المهات الدراسلة.

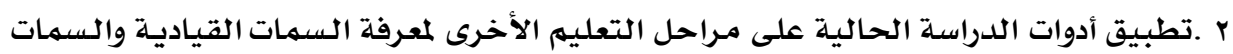

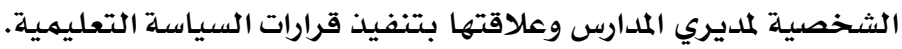




\section{المراجع}

\section{المراجع باللفة العربية :}

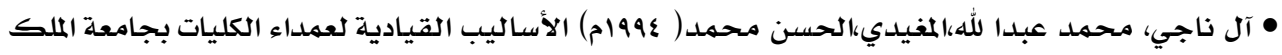

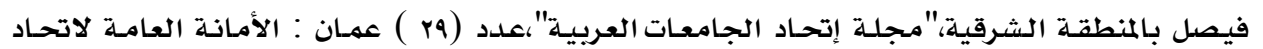

$$
\text { الجامعات العربية }
$$

• الأنصاري، بدر محمد (9qvام)النظريات العاملية للشخصية،الكويت : مكتبة المنار الإسلامية.

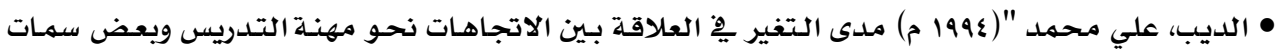

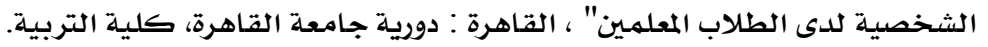

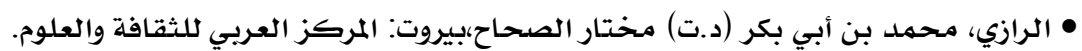

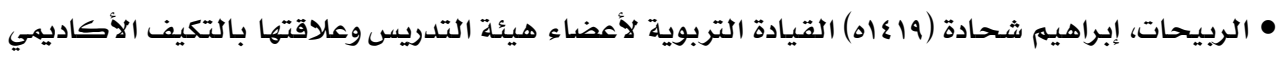

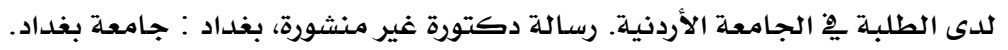

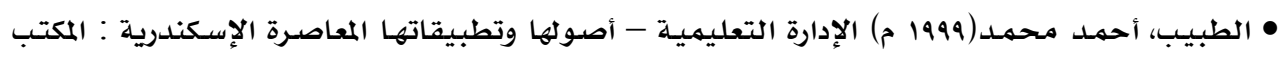

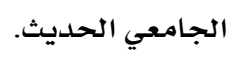

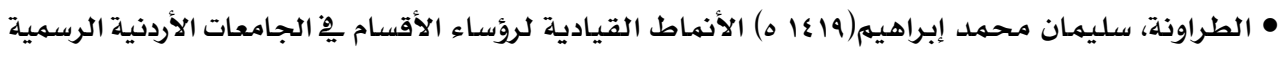

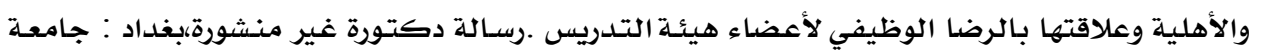
بغداد،كلية التربية -ابن رشدلد.

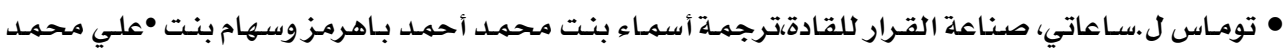

$$
\text { همشري مركز البحوث والدراسات،الرياض،ط (ب..... (r). }
$$

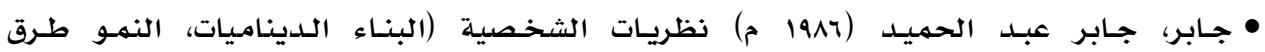

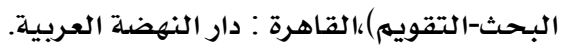

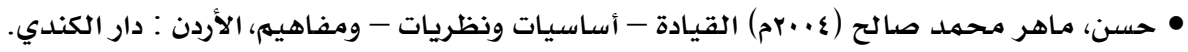

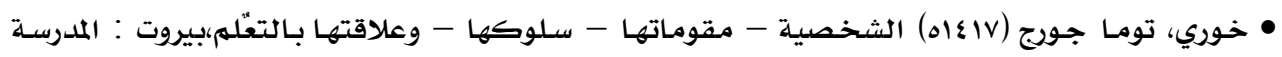
الجامعية للدراسات والنشر.

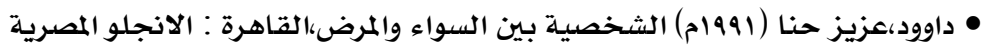

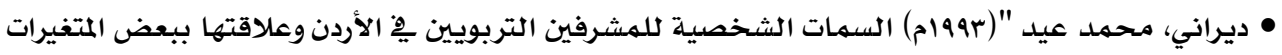

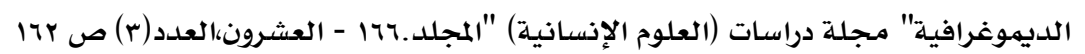

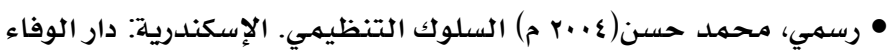

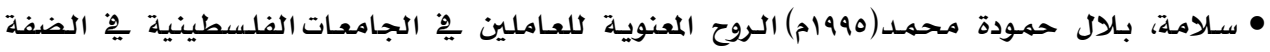

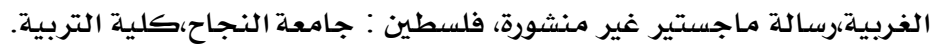

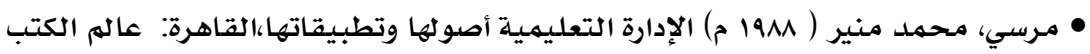

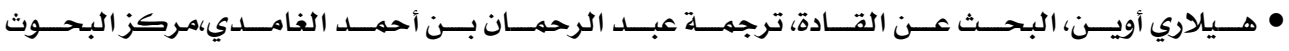

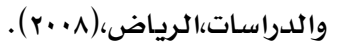




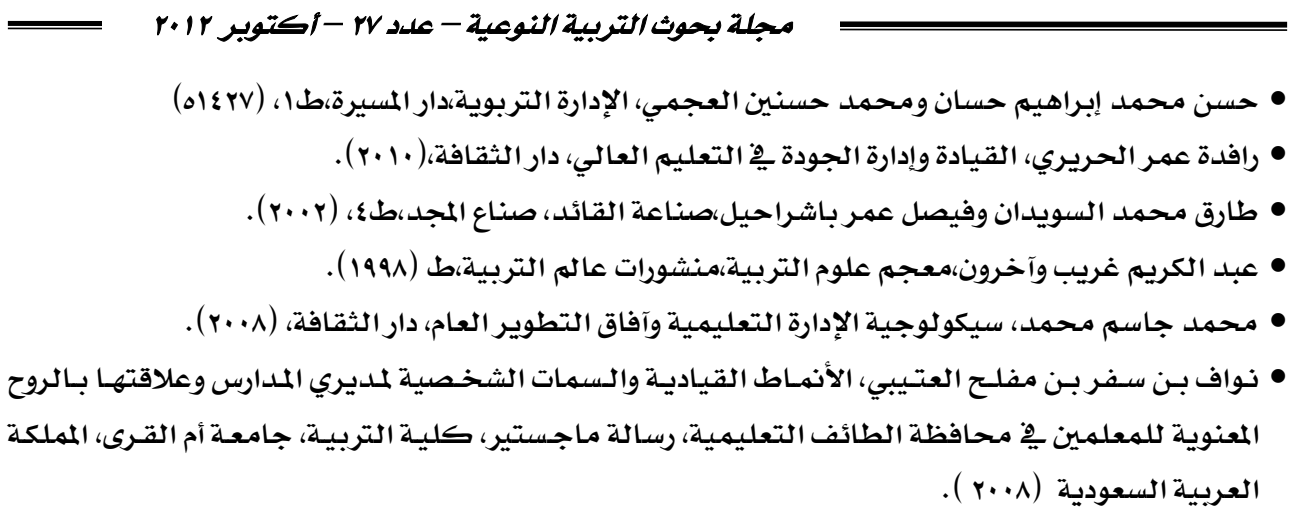

المراجع باللفة الأجنبية:

- Bray, D.W., Campbell, R ,J., and Grant, DL. Formative Years in Business : Along term AT\&T study Of managerial Lives. New York. Wiley, (1974) .

- Ewing, D.W. The Managerial Mind. New York :Free press, (1964)

- Gary A. Yukl, :Leadership in Organizations, New jersey , prentice Hall, INC, Englewood Cliffs. (1980).

- House, R, J., and Mitchll, T.R. "Path-goal Theory of Leadership Contemporary Business, "(1974).

- Katz, D., and Kahn, R.L. The Social Psychology of Organizations Second Edition New York: Wiley,(1978).

- Personality Dimensions and Job Performanve: Ameta -Analysif. ,Personnel Psychology,(1991).

- Palmer, R. F.. The Relationship Between Principals Leadership Style and Faculty Perception of Principals Effectiveness. Dissertation Abstract International, A56, (1996)

- Stogdill, Rm. Handbook Of Leadership: A Survey Of Theory and Research. New York. Free press .(1974) 